\title{
The antihypertensive effect of cysteine
}

\author{
Sudesh Vasdev DVM PhD FICA ${ }^{1}$, Pawan Singal PhD DSc ${ }^{2}$, Vicki Gill BBA ${ }^{1}$
}

S Vasdev, P Singal, V Gill. The antihypertensive effect of cysteine. Int J Angiol 2009;18(1):7-21.

Hypertension is a leading cause of morbidity and mortality worldwide. Individuals with hypertension are at an increased risk for stroke, heart disease and kidney failure. Essential hypertension results from a combination of genetic and lifestyle factors. One such lifestyle factor is diet, and its role in the control of blood pressure has come under much scrutiny. Just as increased salt and sugar are known to elevate blood pressure, other dietary factors may have antihypertensive effects. Studies including the Optimal Macronutrient Intake to Prevent Heart Disease (OmniHeart) study, Multiple Risk Factor Intervention Trial (MRFIT), International Study of Salt and Blood Pressure (INTERSALT) and Dietary Approaches to Stop Hypertension (DASH) study have demonstrated an inverse relationship between dietary protein and blood pressure. One component of dietary protein that may partially account for its antihypertensive

E ssential hypertension affects over 600 million people worldwide (1). It is a vascular disease characterized by increased blood pressure, insulin resistance, oxidative stress and endothelial dysfunction (2-11). A combination of genetic and lifestyle factors is thought to cause hypertension (Figure 1). Diet is one lifestyle factor that has come under much scrutiny. Just as certain dietary factors, such as increased salt and sugar or deficiencies in antioxidants, are known to increase blood pressure (1,12-17), other components of diet may have antihypertensive effects. The Dietary Approaches to Stop Hypertension (DASH) study compared a typical North American diet with the DASH diet, which is rich in vegetables, fruits and low-fat dairy products; low in salt and saturated fat; and included whole grains, poultry, fish, and nuts (18). The DASH diet lowered blood pressure compared with the typical North American diet. When these two diets were modified to contain a similar reduced sodium content, the DASH diet again lowered blood pressure more than the control diet (13). This indicated that a dietary factor other than reduced salt content was having an antihypertensive effect. The DASH diet contained a higher protein content than the North American diet (17.9\% versus $13.8 \%$ ). Several other studies, including the Optimal Macronutrient Intake to Prevent Heart Disease (OmniHeart) study (19), Multiple Risk Factor Intervention Trial (MRFIT) (20) and International Study of Salt and Blood Pressure (INTERSALT) (21), have also demonstrated an inverse relationship between dietary protein and blood pressure. We suggest that the nonessential amino acid cysteine may contribute to this antihypertensive effect.

Several research reports support an antihypertensive role for cysteine. Studies using dietary supplementation of the cysteine analogue $\mathrm{N}$-acetylcysteine (NAC) have shown that, overall, it effect is the nonessential amino acid cysteine. Studies in hypertensive humans and animal models of hypertension have shown that $\mathrm{N}$-acetylcysteine, a stable cysteine analogue, lowers blood pressure, which substantiates this idea. Cysteine may exert its antihypertensive effects directly or through its storage form, glutathione, by decreasing oxidative stress, improving insulin resistance and glucose metabolism, lowering advanced glycation end products, and modulating levels of nitric oxide and other vasoactive molecules. Therefore, adopting a balanced diet containing cysteine-rich proteins may be a beneficial lifestyle choice for individuals with hypertension. An example of such a diet is the DASH diet, which is low in salt and saturated fat; includes whole grains, poultry, fish and nuts; and is rich in vegetables, fruits and low-fat dairy products.

Key Words: Advanced glycation end products; Cysteine; Hypertension; Insulin resistance; Nitric oxide; Oxidative stress

prevents or attenuates increased blood pressure in animal models of hypertension (22-33). Although the cysteine precursor methionine increases the cardiovascular risk factor homocysteine and increases blood pressure in normal rats (34-36), it has been shown to lower blood pressure in hypertensive rats $(35,37)$. Additionally, in human studies, using NAC as an adjunct to other antihypertensive therapies results in a decrease in blood pressure (38-40).

The present review focuses on the normal physiological role of cysteine, examines the evidence of its antihypertensive effects in animal and human studies, and discusses the potential mechanisms by which it exerts its antihypertensive effect.

\section{PHYSIOLOGICAL FUNCTIONS OF CYSTEINE}

Cysteine, a nonessential amino acid, is found in foods such as meats, fish, whole grains, soybeans and legumes (41) (Table 1), and can be formed endogenously via metabolism of its precursor, the essential amino acid methionine (Figure 2). Although nonessential from a dietary perspective, cysteine participates in several essential biological processes.

The chemical structure of cysteine contains a free sulfhydryl (SH) group (Figure 3), and it is this reactive entity that contributes to much of cysteine's biological activity. Cysteine is a component of many structural and functional proteins. One of the most important characteristics of cysteine is its ability to stabilize protein structures by forming disulfide linkages with other cysteine molecules. These covalent cross-links add stability to the three-dimensional structures of protein. This conformational control influences the properties of the protein - for instance, its susceptibility to denaturation (42). This characteristic contributes to maintaining the integrity of vascular structures. The precise location of cysteine within a protein

${ }^{1}$ Discipline of Medicine, Faculty of Medicine, Health Sciences Centre, Memorial University, St John's, Newfoundland; ${ }^{2}$ Institute of Cardiovascular Sciences, St Boniface General Hospital Research Centre, University of Manitoba, Winnipeg, Manitoba

Correspondence and reprints: Dr Sudesh Vasdev, Room H-4310, Health Sciences Centre, Memorial University, St John's, Newfoundland

A1B 3V6. Telephone 709-777-7260, fax 709-777-7010, e-mail svasdev@mun.ca 


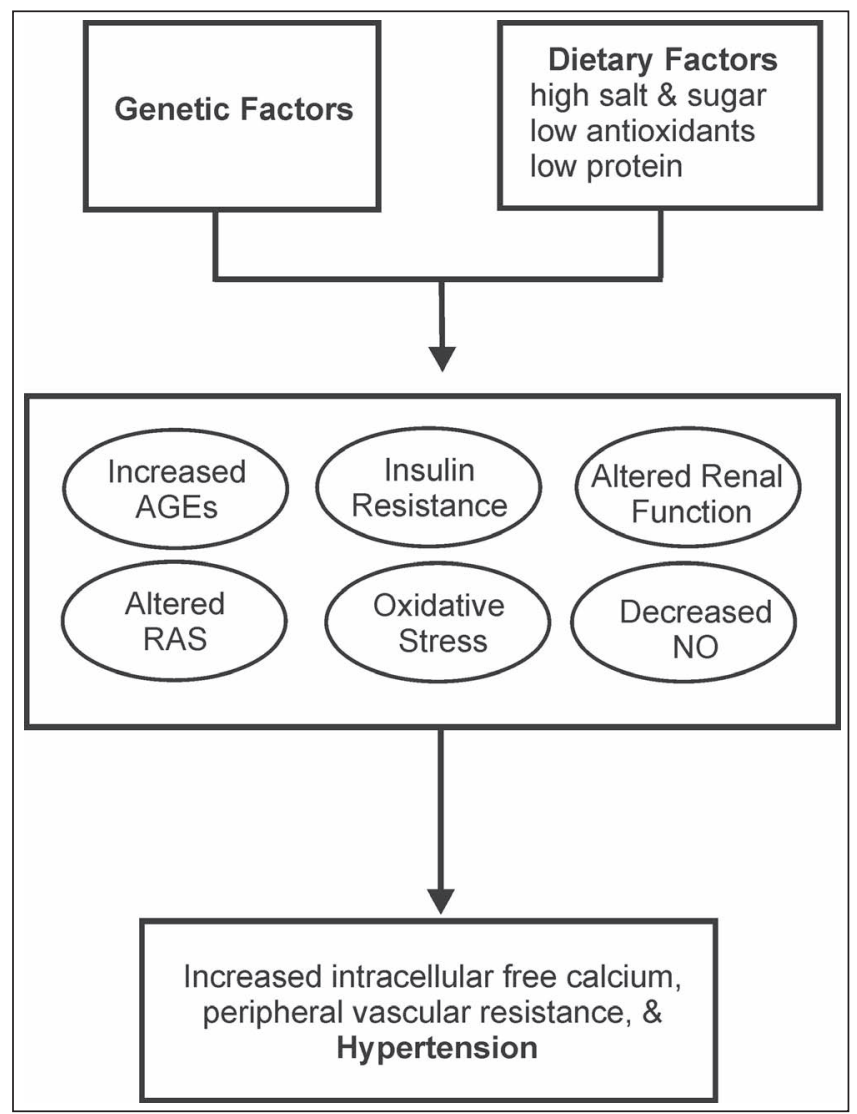

Figure 1) Mechanism of hypertension. Hypertension develops from a combination of genetic and lifestyle factors such as diet. A diet high in salt or sugar, and low in antioxidants and protein, has been implicated in hypertension. Increased oxidative stress and a decreased bioavailability of nitric oxide (NO); insulin resistance and altered glucose metabolism with an increase in advanced glycation end products (AGEs); activation of the renin-angiotensin system (RAS); and damage to kidneys resulting in altered renal function are all mechanisms that contribute to the development of hypertension

also plays a direct role in the protein's function. For example, cysteine is found at the active site of several enzymes, including the vascular enzyme endothelial nitric oxide (NO) synthase (eNOS) (43), and regulates catalytic activity. As a moderately powerful redox pair, cysteine and its disulfide partner cystine have an important physiological function as antioxidants. Additionally, cysteine is a rate-limiting substrate in the biosynthesis of reduced glutathione, a tripeptide, which also contains glutamate and glycine (Figure 3). Here again, the free $\mathrm{SH}$ group of cysteine within glutathione confers functional properties to this molecule. Reduced glutathione/oxidized glutathione (GSH/GSSG) is a ubiquitous and powerful antioxidant pair found in all cells of the body (Table 2). GSH is involved in the enzymatic reduction (catalyzed by glutathione peroxidase) of hydrogen peroxide $\left(\mathrm{H}_{2} \mathrm{O}_{2}\right)$ and lipid hydroperoxides. Due to its high redox potential, GSH plays a major role in regenerating other antioxidants to their reduced states, consequently increasing overall antioxidant capacity $(44-46)$. GSH is an essential component of the glyoxalase enzyme system, which is responsible for catabolism of the highly reactive aldehydes methylglyoxal and glyoxal (47). Glutathione and cysteine also
TABLE 1

Dietary sources of cysteine

\begin{tabular}{|c|c|c|}
\hline Food & Serving & Cysteine (mg) \\
\hline \multicolumn{3}{|l|}{ Meat } \\
\hline Lamb, leg and shoulder, braised & $3.5 \mathrm{oz}(100 \mathrm{~g})$ & 402 \\
\hline Chicken breast, without skin, roasted & $1 / 2$ breast $(86 \mathrm{~g})$ & 341 \\
\hline Pork, Boston blade, roasted & $3.5 \mathrm{oz}(100 \mathrm{~g})$ & 316 \\
\hline Beef, chuck roast, braised & $3.5 \mathrm{oz}(100 \mathrm{~g})$ & 370 \\
\hline \multicolumn{3}{|l|}{ Fish } \\
\hline Salmon, baked & 3 oz (85 g) & 232 \\
\hline Halibut, baked & $3 \mathrm{oz}(85 \mathrm{~g})$ & 243 \\
\hline Tuna, canned, light & $3 \mathrm{oz}(85 \mathrm{~g})$ & 232 \\
\hline \multicolumn{3}{|l|}{ Grains } \\
\hline Barley, pearled, light & $1 / 2$ cup $(100 \mathrm{~g})$ & 219 \\
\hline Oat bran, cooked & $1 / 2$ cup $(110 \mathrm{~g})$ & 108 \\
\hline Whole wheat flour & 1 cup $(120 \mathrm{~g})$ & 381 \\
\hline Quinoa & $1 / 2 \operatorname{cup}(85 \mathrm{~g})$ & 456 \\
\hline \multicolumn{3}{|l|}{ Soybean products } \\
\hline Soybean flour, defatted & 1 cup $(100 \mathrm{~g})$ & 757 \\
\hline Soy milk & 1 cup $(240 \mathrm{~g})$ & 113 \\
\hline Soybeans, boiled & 1 cup $(172 \mathrm{~g})$ & 461 \\
\hline Tofu, raw, firm & $1 / 2 \operatorname{cup}(126 \mathrm{~g})$ & 275 \\
\hline \multicolumn{3}{|l|}{ Dairy } \\
\hline Cottage cheese, low-fat & 1 cup $(226 \mathrm{~g})$ & 287 \\
\hline Cow milk, 1\% & $8 \mathrm{oz}(244 \mathrm{~g})$ & 74 \\
\hline Chicken eggs, boiled & 1 large $(50 \mathrm{~g})$ & 146 \\
\hline \multicolumn{3}{|l|}{ Other } \\
\hline Almonds, blanched & $1 \mathrm{oz}(28 \mathrm{~g})$ & 133 \\
\hline Split peas, boiled & 1 cup $(196 \mathrm{~g})$ & 249 \\
\hline Broadbeans, boiled & 1 cup (170 g) & 165 \\
\hline Figs, dried & 10 (187 g) & 94 \\
\hline Avocado, medium & $1(304 \mathrm{~g})$ & 52 \\
\hline
\end{tabular}

Data from reference 41

bind these aldehydes, causing them to be excreted in bile and urine (48).

Glutathione comprises $90 \%$ of the total nonprotein low molecular weight thiols in the body. Together with cysteine, glutathione forms part of an endogenous thiol pool that reacts with the vasoregulatory molecule $\mathrm{NO}$ to form nitrosothiol, thus stabilizing this normally volatile molecule (49-51). In this way, nitrosothiol increases the bioavailability of $\mathrm{NO}$ and potentiates $\mathrm{NO}$-mediated effects, such as vasorelaxation, as well as antiaggregatory and anti-inflammatory processes. Nitrosothiol also has independent biological activity, similar to that of $\mathrm{NO}(49,52-55)$. In a later section of the present review, S-nitrosothiols (SNOs) are discussed in detail.

Proteins and amino acids are also sources of energy. Amino acids stimulate insulin secretion, which subsequently leads to their cellular uptake and protein synthesis (56). It was demonstrated earlier that cysteine also has insulin-like actions, such as promoting glucose uptake into adipose cells, an action mediated by its free SH groups (57). Cysteine has been subsequently shown to increase the levels of glucose transporter (GLUT) 3 and GLUT 4 (58). Thus, cysteine likely plays a role in balancing energy metabolism.

To summarize, cysteine influences structure and function of proteins, and acts both directly and indirectly through glutathione to control oxidative stress, maintain reactive aldehydes at low levels, increase bioavailability of $\mathrm{NO}$, and influence insulin and glucose metabolism. Because various proteins and 


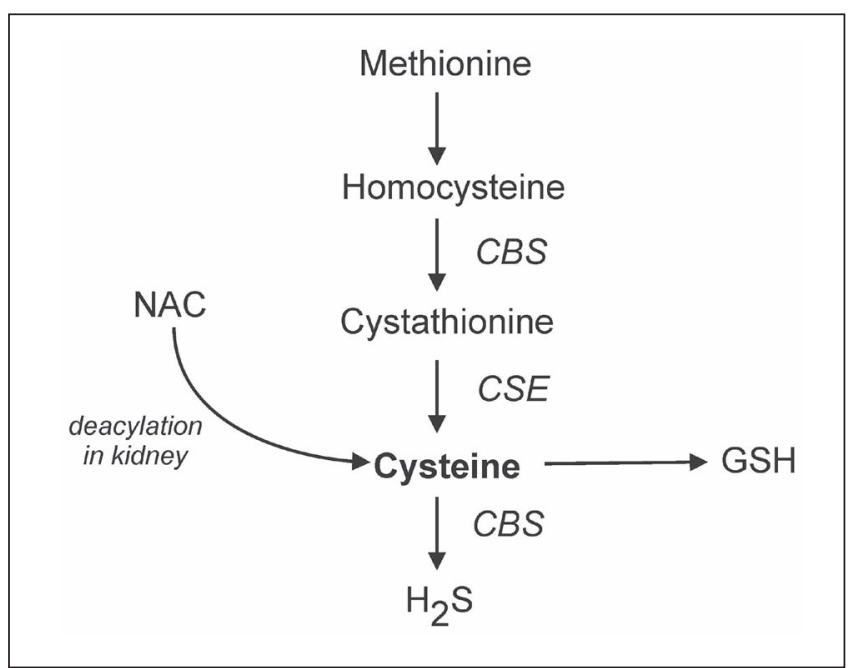

Figure 2) Metabolic formation of cysteine. Methionine, an essential amino acid obtained through diet, is converted via an enzymatic pathway to the thiol-containing amino acid cysteine. This pathway includes the vitamin $\mathrm{B}_{6}$-dependent enzymes cystathionine betasynthase (CBS) and cystathionine gamma-lyase (CSE). $N$-acetylcysteine (NAC), a cysteine analogue also available in the diet, is deacylated to cysteine primarily in the kidneys. Cysteine may be further converted to the ubiquitious antioxidant glutathione (GSH) or enzymatically converted into the vasoactive molecule $\mathrm{H}_{2} \mathrm{~S}$ via $\mathrm{CBS}$

processes involved in vascular function are influenced by oxidative, carbonyl or nitrosative stimuli $(43,59-67)$, cysteine potentially plays an important role in regulating blood pressure. This indicates that a disruption in cysteine or glutathione availability, or an increased demand on these thiols, contributes to the etiology of hypertension. It further suggests that supplementary agents such as NAC, which increase endogenous levels of these thiols, or intake of dietary NAC or cysteinecontaining proteins, may be useful in controlling high blood pressure. The following section presents the results of various animal (Table 3) and human (Table 4) studies that investigated the effects of cysteine supplementation on blood pressure. Throughout the present review, doses of NAC or methionine are given at the first occurrence of the citation.

\section{EFFECT OF CYSTEINE ON BLOOD PRESSURE}

\section{Animal studies}

Because cysteine is rapidly oxidized in the air, it can not be added, as is, to animal diet or drinking water. NAC, a cysteine analogue found naturally in several fruits and vegetables (68), is stable and also available as a commercial preparation. In the body, NAC is deacylated, primarily in the kidneys, to produce cysteine. Many studies investigating the effect of cysteine use either NAC or methionine, the metabolic precursor to cysteine. Rats are used to model human hypertension, and although these models are not perfect, they do generally represent disease conditions, and are most convenient for studying in vivo mechanisms of disease and response to treatments.

The following studies investigated the antihypertensive effect of NAC in spontaneously hypertensive rats (SHRs), a genetic model of hypertension. In an acute study of the angiotensinconverting enzyme (ACE) inhibitors captopril and enalaprilat,

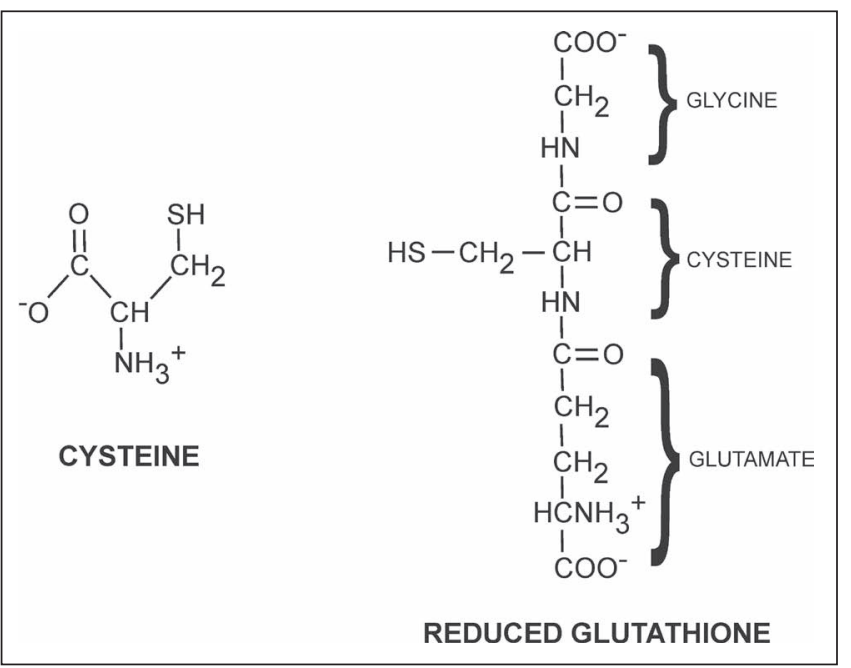

Figure 3) Chemical structures of cysteine and reduced glutathione. Free sulfhydryl groups of these molecules contribute to much of their biological activity

TABLE 2

Redox potentials of antioxidants in mammalian oxidation systems

\begin{tabular}{lc}
\hline Redox pair & $\mathrm{E}^{\prime}{ }_{\mathrm{o}}(\mathrm{V})$ \\
\hline $\mathrm{O}_{2} / \mathrm{H}_{2} \mathrm{O}$ & +0.82 \\
Vitamin E oxidized/reduced & +0.37 \\
Ubiquinone oxidized/reduced & +0.10 \\
Vitamin C oxidized/reduced & +0.08 \\
Cystine/cysteine & -0.22 \\
$\mathrm{GSSG} / \mathrm{GSH}$ & -0.24 \\
$\mathrm{Lipoate}$ oxidized/reduced & -0.29 \\
$\mathrm{NAD}^{+} / \mathrm{NADH}$ & -0.32 \\
$\mathrm{H}^{+} / \mathrm{H}_{2}$ & -0.42 \\
\hline
\end{tabular}

Redox pairs given by increasing electronegativity and antioxidant activity. $E_{0}^{\prime}$ Standard reduction potential; GSSG/GSH Glutathione oxidized/reduced

intravenous pretreatment with $300 \mathrm{mg} / \mathrm{kg}$ body weight (bw) of NAC was shown to potentiate the blood pressure-lowering effects of these traditional antihypertensive drugs in SHRs (22). Oral NAC treatment of $4 \mathrm{~g} / \mathrm{kg}$ bw/day in drinking water for two weeks was shown to reduce systolic but not diastolic blood pressure (24), while the same dose given for four weeks reduced mean arterial blood pressure in this model (25). A study using a lower dose of NAC, $1.5 \mathrm{~g} / \mathrm{kg}$ bw/day in drinking water for six weeks, showed no effect on blood pressure (69). However, an even lower dose of NAC, $760 \mathrm{mg} / \mathrm{kg}$ bw/day in the diet for a longer interval of 11 weeks, normalized blood pressures in these animals (23). These studies analyzed the ability of NAC to treat SHRs that were already hypertensive. One study (26) in young prehypertensive SHRs demonstrated that chronic NAC treatment with $1.5 \mathrm{~g} / \mathrm{kg}$ bw/day in drinking water for eight weeks attenuated the rise in blood pressure. On the whole, these studies showed that NAC treatment has antihypertensive effects in this genetic model of hypertension.

Dahl salt-sensitive (DSS) rats are salt-sensitive models of hypertension - their blood pressure rises with increasing levels of dietary salt. Studies of NAC supplementation in this model are scant. NAC, $15 \mathrm{~g} / \mathrm{L}$ in drinking water for four weeks, prevented an increase in systolic blood pressure in rats 
TABLE 3

The effect of cysteine on blood pressure (BP) in animal models of hypertension

\begin{tabular}{lll}
\hline Animal model & Dose/duration & Effect on BP (reference) \\
\hline SHRs given ACE inhibitors (captopril or enalapril) & $300 \mathrm{mg}$ intravenous NAC/kg bw & $\begin{array}{c}\text { Potentiated the antihypertensive effect of concomitant } \\
\text { ACE inhibitor (22) }\end{array}$ \\
SHRs & $760 \mathrm{mg} \mathrm{NAC} / \mathrm{kg}$ bw/day for 11 weeks in drinking & $\begin{array}{c}\text { Normalized elevated SBP (23) } \\
\text { SH }\end{array}$
\end{tabular}

water

$4 \mathrm{~g} \mathrm{NAC} / \mathrm{kg}$ bw/day for 2 weeks in drinking water

$4 \mathrm{~g} \mathrm{NAC} / \mathrm{kg}$ bw/day for 4 weeks in drinking water

$1.5 \mathrm{~g} \mathrm{NAC} / \mathrm{kg}$ bw/day for 6 weeks in drinking water

$1.5 \mathrm{~g} \mathrm{NAC} / \mathrm{kg}$ bw/day for 8 weeks in drinking water

$500 \mathrm{mg}$ methionine/kg bw/day for 10 weeks in diet

Decreased SBP but not DBP (24)

Decreased MAP (25)

No effect on SBP (67)

Prevented the rise in SBP, DBP and MAP in young SHRs; no effect in adult SHRs (26)

Increased SBP in control WKY rats and attenuated an increase in SHRs (35)

DOCA-treated SD rats

$500 \mathrm{mg}$ methionine/kg bw/day for 10 weeks in diet

Increased BP in control SD rats and attenuated a rise in SBP in DOCA rats (37)

DSS rats treated with high-salt diet

$15 \mathrm{~g} \mathrm{NAC/L}$ drinking water for 4 weeks $4 \mathrm{~g} \mathrm{NAC/kg} \mathrm{bw/day} \mathrm{for} 5$ weeks in diet $10 \mathrm{~g} \mathrm{NAC/L}$ drinking water for 4 weeks

Prevented an increase in SBP (27)

Prevented an increase in MAP (28)

Prevented an increase in MAP (29)

Prevented an increase in SBP (30)

WKY rats treated with $4 \%$ fructose in drinking water SD rats treated with $60 \%$ fructose in drinking water L-NAME-treated Wistar rats

$664 \mathrm{mg} \mathrm{NAC} / \mathrm{kg}$ bw/day for 11 weeks in diet

Prevented an increase in SBP and DBP (31)

$1.5 \mathrm{~g} \mathrm{NAC} / \mathrm{kg}$ bw/day for 12 weeks in drinking wate

$1.5 \mathrm{~g} \mathrm{NAC} / \mathrm{kg}$ bw/day for 4 weeks in drinking water

Prevented the L-NAME-induced increase in MAP (32)

$1.5 \mathrm{~g} \mathrm{NAC} / \mathrm{kg}$ bw/day for 5 weeks in drinking water

Attenuated the L-NAME-induced increase in MAP (33)

ACE Angiotensin-converting enzyme; bw Body weight; D Diastolic; DOCA Deoxycorticosterone acetate salt; DSS Dahl salt-sensitive; L-NAME N-(omega)-nitro-Larginine methyl ester; MAP Mean arterial pressure; NAC N-acetylcysteine; S Systolic; SD Sprague-Dawley, SHR Spontaneously hypertensive rat; WKY WistarKyoto

\section{TABLE 4}

Effect of cysteine on blood pressure (BP) in humans with hypertension

\begin{tabular}{|c|c|c|}
\hline Human subjects & Dose/duration & Effect on BP (reference) \\
\hline $\begin{array}{l}\text { Hypertensive subjects } \\
\text { receiving ACE inhibitor } \\
\text { lisinopril }\end{array}$ & $\begin{array}{l}1.2 \mathrm{~g} / \text { day oral } \\
\text { NAC for } 1 \text { week }\end{array}$ & $\begin{array}{l}\text { Decreased SBP and DBP } \\
\text { (38) }\end{array}$ \\
\hline $\begin{array}{l}\text { Hypertensive subjects who } \\
\text { smoked and were receiving } \\
\text { ACE inhibitors captopril or } \\
\text { enalapril }\end{array}$ & $\begin{array}{l}1.8 \text { g/day oral } \\
\text { NAC for } \\
3 \text { weeks }\end{array}$ & $\begin{array}{l}\text { Decreased } 24 \mathrm{~h} \\
\text { ambulatory and daytime } \\
\text { SBP and DBP (39) }\end{array}$ \\
\hline $\begin{array}{l}\text { Hypertensive subjects with } \\
\text { type } 2 \text { diabetes whose } \\
\text { previous antihypertensive } \\
\text { medications were } \\
\text { discontinued } 15 \text { days } \\
\text { before study }\end{array}$ & $\begin{array}{l}1.2 \mathrm{~g} / \text { day NAC } \\
\text { plus } 1.2 \text { g/day } \\
\text { arginine orally } \\
\text { for } 6 \text { months }\end{array}$ & $\begin{array}{l}\text { Decreased SBP, DBP and } \\
\text { mean arterial BP }(40)\end{array}$ \\
\hline
\end{tabular}

ACE Angiotensin-converting enzyme; D Diastolic; NAC N-acetylcysteine; S Systolic

fed a high-salt diet $(8 \% \mathrm{NaCl})(27)$. In a five-week study of rats on a high-salt diet, $4 \mathrm{~g} / \mathrm{kg}$ bw/day of NAC in the diet prevented an increase in mean arterial blood pressure (28). In an abstract, Kunes et al (29) reported that $10 \mathrm{~g} / \mathrm{L}$ of NAC in drinking water for four weeks prevented hypertension in young rats. Although few in number, these studies concur in their findings that NAC effectively prevented a salt-induced increase in blood pressure in this model.

Fructose-fed rats represent a model of diet-induced or acquired hypertension. Wistar-Kyoto (WKY) rats fed $4 \%$ fructose in drinking water for 11 weeks developed an increase in systolic blood pressure, which was prevented by $664 \mathrm{mg} / \mathrm{kg}$ bw/day of $\mathrm{NAC}$ in the diet (30). NAC, $1.5 \mathrm{~g} / \mathrm{kg}$ bw/day in drinking water for 12 weeks, also prevented an increase in systolic and diastolic blood pressures in Sprague-Dawley (SD) rats given 60\% fructose (31). These two studies agree in their results, adding to the weight of evidence indicating that cysteine lowers blood pressure.

Hypertension is associated with a reduced bioavailability of the vasodilator $\mathrm{NO}$ with consequent endothelial dysfunction $(9,11)$. A model of hypertension that seeks to mimic these conditions is the $\mathrm{N}$-(omega)-nitro-L-arginine methyl ester (L-NAME)-treated rat. L-NAME inhibits NO synthase (NOS), the enzyme that catalyzes the formation of NO, causing a reduction in NO-mediated vasodilation. L-NAME treatment in Wistar rats for four weeks caused an increase in mean arterial pressure that was prevented by NAC supplementation of $1.5 \mathrm{~g} / \mathrm{kg}$ bw/day in drinking water (32). In a similar five-week study, NAC attenuated the development of L-NAME-induced hypertension (33). The concurrence of these studies suggests that NAC compensates for the L-NAME-induced loss of NO to reduce blood pressure in this model.

The essential amino acid methionine is metabolized endogenously to cysteine (Figure 2). However, homocysteine, a cardiovascular disease risk factor (34), is also increased when dietary methionine is increased $(35,36)$. In one study, intake of a diet supplemented with $500 \mathrm{mg} / \mathrm{kg}$ bw/day of methionine for 10 weeks caused similar elevations in plasma homocysteine in normotensive WKY control rats and SHRs. However, it resulted in a moderate increase in systolic blood pressure in WKY control rats, while it attenuated the increase in blood pressures in SHRs (35). Similarly, these authors reported that methionine supplementation increased blood pressure in another type of normotensive control rat, SD rats, while attenuating a blood pressure increase in a deoxycorticosterone acetate (DOCA) salt hypertensive rat model (37). These reports of opposite effects on blood pressure in normotensive and hypertensive animals, combined with the potential increased risk of cardiovascular disease, may preclude the use of methionine supplementation for the control of blood pressure 
in humans. However, this research contributes to the body of data demonstrating the blood pressure-lowering effect of cysteine in hypertensive models. Collectively, these studies in various rat models of hypertension provide evidence that cysteine lowers blood pressure or prevents its increase.

\section{Human studies}

There are no reported studies using NAC as a monotherapy in humans with hypertension. However, in one study of six hypertensive subjects exhibiting fairly good blood pressure control (average of 139/93 $\mathrm{mmHg}$ ) with the ACE inhibitor lisinopril, the addition of NAC, $1.2 \mathrm{~g} /$ day for one week, caused a significant decrease in both the systolic and diastolic blood pressures (38). In a second study, 18 hypertensive smokers whose blood pressures were not controlled with ACE inhibitor monotherapy (enalapril or captopril) were given adjunct treatment with NAC, $1.8 \mathrm{~g} /$ day for 21 days, resulting in a decrease in $24 \mathrm{~h}$ ambulatory and daytime systolic and diastolic blood pressures (39). Because neither of these studies included subjects treated with only NAC, we cannot discern whether NAC potentiated the effect of the ACE inhibitors, or whether there was an independent additive antihypertensive effect of NAC. A third study examined the effect of a combination of NAC, $1.2 \mathrm{~g} /$ day, and an equal dose of arginine, the substrate of NOS, in a group of 12 type 2 diabetic patients with hypertension (40). Traditional antihypertensive therapy was stopped and followed by a 15-day washout period before the combination treatment was started. Compared with basal levels, systolic, diastolic and mean arterial pressures were reduced after six months of combined treatment. This combination treatment using the NOS substrate and an antioxidant may work by concomitantly increasing $\mathrm{NO}$ production and preserving its destruction by reactive oxygen species (ROS). Of note, none of these studies in humans reported any adverse effects of NAC. Studies using $\mathrm{NAC}$ as a monotherapy are necessary to confirm its antihypertensive effect in humans.

\section{POTENTIAL MECHANISMS OF ANTIHYPERTENSIVE ACTION}

The preponderance of evidence from these animal and human studies demonstrates the antihypertensive effect of cysteine. The potential mechanisms of antihypertensive action of cysteine are discussed next (Figure 4).

\section{Cysteine lowers oxidative stress}

An imbalance in which ROS or reactive nitrogen species (RNS) outweigh antioxidant capacity is known as oxidative stress. This may occur due to an increased production of reactive species or a diminished neutralizing capacity, or both. Reactive species are generated from various sources within the body. NO itself is a reactive molecule that gives rise to RNS including peroxynitrite and peroxynitrous acid, which are unstable and result in the production of hydroxyl radicals $(\bullet \mathrm{OH})(70)$. This not only increases oxidative stress but also decreases the bioavailability of NO. In vascular tissue, the membrane enzyme NADPH oxidase is a major source of superoxide radical $\left(\mathrm{O}_{2}^{-}\right)$, which further gives rise to radicals such as $\mathrm{H}_{2} \mathrm{O}_{2}$ and $\bullet \mathrm{OH}(71)$. These reactive species are controlled enzymatically by superoxide dismutase (SOD), glutathione peroxidase and glutathione reductase. They are also controlled

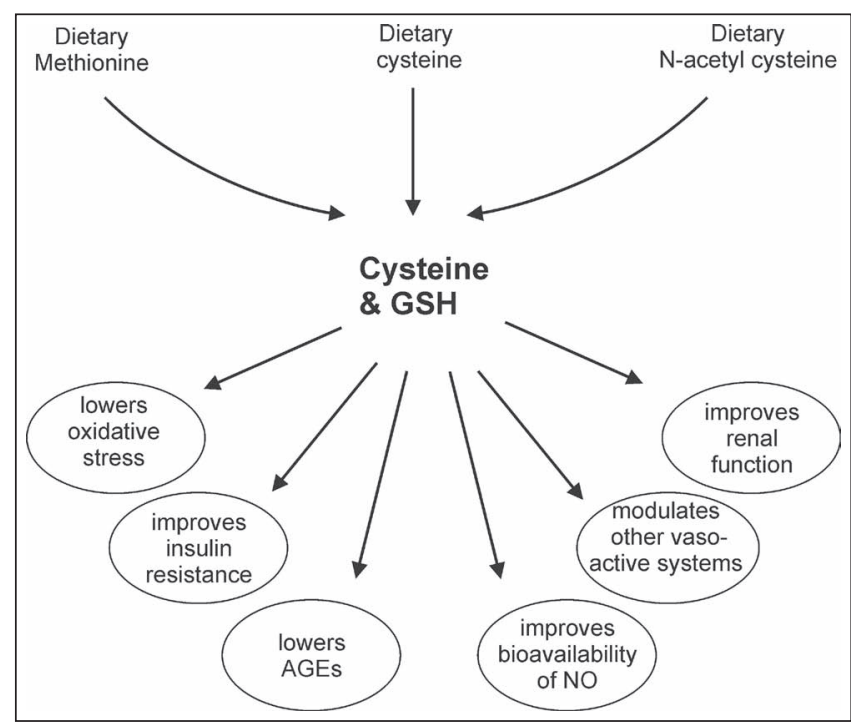

Figure 4) Sources and antihypertensive actions of cysteine and glutathione (GSH). Cysteine is derived from dietary methionine, cysteine or $\mathrm{N}$-acetylcysteine. It exerts its antihypertensive action directly, or indirectly through its storage form GSH. Cysteine decreases blood pressure by lowering oxidative stress, improving insulin resistance, altering glucose metabolism to lower advanced glycation end products (AGEs), improving the bioavailability of nitric oxide (NO), modulating other vasoactive molecules such as angiotensin $\mathrm{II}$ and $\mathrm{H}_{2} \mathrm{~S}$, and improving renal function

nonenzymatically by vitamins such as vitamin $\mathrm{E}$ and $\mathrm{C}$, or by thiol compounds including cysteine and glutathione.

Under normal circumstances, ROS and RNS may play a role in vascular homeostasis. They are involved in control of intracellular calcium levels (59-61); activity of vascular enzymes including NOS (43) and ACE $(62,72)$, and glycolytic enzymes such as glyceraldehyde 3-phosphate dehydrogenase and glucose-6-phosphate dehydrogenase $(63,73,74)$; function of membrane receptors and cell signalling activity (75-79); and gene transcription (64). Thus, when there is oxidative stress, dysfunction of these proteins may result in altered cell signalling and protein expression $(64,79)$, decreased $\mathrm{NO}(7,80)$ and increased angiotensin II (AII) (62), altered glucose metabolism (73) and increased intracellular calcium $(60,81)$. This can result in changes characteristic of hypertension, including insulin resistance, increased cytosolic free calcium, vasoconstriction and peripheral vascular resistance, and vascular smooth muscle cell (VSMC) proliferation.

Oxidative stress is increased in animal models and humans with hypertension. SHRs, DSS rats, and fructose- and saltinduced hypertensive rats all show an increase in oxidative stress and a reduction in antioxidant capacity (27,31,82-86). Humans with essential hypertension show an elevation in $\mathrm{O}_{2}{ }^{-}$ and $\mathrm{H}_{2} \mathrm{O}_{2}$ production by polymorphonuclear cells $(4,7,8)$, an increase in lipid peroxidation parameters in serum or plasma $(5,6,8,87-89)$, and a decline in antioxidant capacity $(5,6,87,89)$.

Cysteine may regulate blood pressure in part by acting as an antioxidant, either directly or via glutathione to reduce oxidative stress. As previously discussed, cysteine/cystine and GSH/ GSSG are powerful redox pairs that are directly involved in 
neutralizing reactive species and increasing antioxidant capacity. NAC has also been shown to reduce oxidative stress in isolated cells, and in animals and humans. During in vitro testing, NAC was a powerful scavenger of the reactive species $\mathrm{HOCl}$ and $\bullet \mathrm{OH}$; it also reacted slowly with $\mathrm{H}_{2} \mathrm{O}_{2}$ and not at all with $\mathrm{O}_{2}^{-}(90)$. However, another study showed that NAC added in vitro to neutrophils of healthy subjects inhibited chemiluminescence, a measure of superoxide production (91). NAC decreased lipid peroxidation in liposomes of bovine brain extract by $50 \%$ (92). A cell culture study using T lymphocytes from children with chronic renal failure showed that incubation with NAC decreased intracellular oxidative stress and ROS-mediated apoptosis (93). Addition of NAC to isolated rabbit heart increased glutathione content in a dose-dependent manner and protected against oxidative ischemic reperfusion injury (94).

In in vivo animal studies of hypertension, NAC not only reduced blood pressure but also was effective at reducing oxidative stress and improving antioxidant capacity. NAC treatment increased aortic GSH content, lowered the GSSG/GSH ratio and malondialdehyde levels, and protected against peroxynitrite-induced endothelial dysfunction in both WKY rats and SHRs (24). In SHRs, treatment with NAC decreased conjugated dienes, a measure of oxidative stress, in the left ventricle and kidney (26). In young SHRs, a combination of NAC, $200 \mathrm{mg} / \mathrm{kg}$ bw/day, given intraperitoneally, and tempol, the SOD mimetic, $250 \mathrm{mg} / \mathrm{kg}$ bw/day given intraperitoneally for one week, lowered renal nitrotyrosine levels, an indicator of tissue oxidative and nitrosative stress (82). Although a diet supplemented with methionine did not increase plasma cysteine levels in SHRs, it did increase plasma GSH levels (35). In high salt-treated DSS rats, supplementation with NAC diminished renal NADPH oxidase activity and expression, and lowered urinary levels of $\mathrm{H}_{2} \mathrm{O}_{2}$ and 8-isoprostanes, a marker of lipid peroxidation (27). Another study in this model showed that NAC treatment lowered superoxide release and increased the GSH/GSSG ratio in the kidneys (28). NAC supplementation with $1.44 \mathrm{~g} / \mathrm{kg}$ bw/day in drinking water for eight weeks in type 1 diabetic rats reduced plasma and myocardial free $15-\mathrm{F}_{2 \mathrm{t}}$-isoprostanes, and increased plasma SOD activity and GSH (95). A similar result was found in fructose-fed hypertensive rats, in which NAC supplementation abolished the increase in plasma $15-\mathrm{F}_{2 \mathrm{t}}$-isoprostanes (31). In high sucrose-fed Wistar rats, addition of oral NAC, $2 \mathrm{mg} / \mathrm{L}$ in drinking water, increased SOD and GSH levels, glutathione peroxidase activity and the GSH/GSSG ratio (85). NAC given to L-NAMEtreated rats prevented an increase in superoxide production in the aorta and conjugated diene levels in the left ventricle and kidney (32). Another study in this rat model showed that two weeks of supplementation with $75 \mathrm{mg}$ /day of NAC in drinking water normalized cardiac glutathione levels (96).

Although studies assessing the effect of NAC on oxidative stress and antioxidant capacity in humans are few, those that have been documented show positive results. In a study of healthy subjects, a single $400 \mathrm{mg}$ oral dose of NAC lowered neutrophil chemiluminescence (97). Oral NAC, $1.2 \mathrm{~g} /$ day for four weeks, given to type 2 diabetic patients increased intraerythrocytic GSH levels and the GSH/GSSG ratio (98). In type 2 diabetic hypertensive patients, a combination of NAC and $\mathrm{L}$-arginine supplementation lowered plasma nitrotyrosine
(40). Taken together, these experimental and human studies demonstrate that cysteine decreases oxidative stress and increases antioxidant capacity.

\section{Cysteine improves insulin resistance}

Insulin is a hormone that regulates carbohydrate and lipid metabolism, and stimulates protein synthesis. The effects of insulin are initially mediated by the binding of the hormone to the insulin receptors on the cell surface. The tyrosine kinase activity of the receptor then stimulates a number of intracellular signalling cascades known as insulin signalling. This signalling not only promotes glucose uptake but modulates other functions involved in blood pressure regulation, such as NO-mediated vasodilation $(99-102)$, AII signalling $(103,104)$ and antinatriuretic activity (105).

Insulin resistance is characterized by inadequate glucose uptake with altered glucose metabolism in peripheral tissues at a given concentration of plasma insulin (2). There is increasing evidence that insulin resistance plays a key role in essential hypertension in humans $(2,3,106)$. Abnormalities in glucose use are estimated to exist in $25 \%$ of the general population and in up to $80 \%$ of subjects with essential hypertension $(2,107$ 109). In humans with essential hypertension, insulin resistance involves impairment of the nonoxidative (glycolytic) pathways of intracellular glucose metabolism (2). Insulin resistance appears to be a primary defect because it exists in normotensive individuals at risk for essential hypertension (110). Studies show the presence of insulin resistance in SHRs at a young age $(111,112)$ and before development of hypertension (113). Insulin resistance is also a characteristic of salt-sensitive rats and humans with hypertension (114-118). In genetic, salt- and sugar-induced rat models of hypertension, there is impairment in the insulin receptor substrate (IRS)/phosphatidylinositol 3-kinase (PI3K)/protein kinase B (Akt) and IRS/PI3K/Akt/ eNOS insulin signalling pathways $(86,117-120)$. ROS have been shown to inhibit insulin signalling in VSMCs (79).

Cysteine may exert antihypertensive effects by improving insulin resistance and glucose metabolism. An early study demonstrated that cysteine has an insulin-like action, promoting the entry of glucose into adipose cells, mediated by its free SH group (57). GLUT 3 and GLUT 4 were increased, and a marked enhancement of glucose uptake was demonstrated, in mouse soleus muscle and human neuroblastoma cells when exposed to cysteine (58). NAC significantly reduced high sucrose-induced hyperglycemia in Wistar rats (85). Increasing the cysteine-containing protein content in the diet or supplementing the diet with NAC, $5.8 \mathrm{~g} / \mathrm{kg}$ or $20 \mathrm{~g} / \mathrm{kg}$ of food, prevented oxidative stress and insulin resistance in sucrose-fed Wistar rats (86). Fructose-induced hypertensive SD rats showed an increase in plasma insulin and a decrease in insulin sensitivity that was attenuated by NAC in diet (31). Similarly, another study in fructose-treated WKY rats showed that NAC normalized elevated plasma glucose and insulin (30). Intravenous administration of NAC, $0.5 \mathrm{mg} / \mathrm{kg}$ to $2 \mathrm{mg} / \mathrm{kg} \mathrm{bw}$, increased glucose use during a hyperglycemic clamp test in healthy volunteers (121). The homeostasis model assessment, an index of insulin sensitivity, was reduced in a group of obese, nondiabetic patients. Supplementation with $600 \mathrm{mg} / \mathrm{day}$ NAC for eight weeks increased the homeostasis model assessment in these patients (122). Treatment with $1.8 \mathrm{~g} /$ day to $3 \mathrm{~g} /$ day NAC for 
five to six weeks also improved insulin sensitivity in women with polycystic ovarian syndrome, another condition with insulin resistance (123). It has also been suggested that cysteine may improve glucose metabolism by preventing oxidative or nitrosative inhibition of the glycolytic enzymes glucose-6phosphate dehydrogenase and glyceraldehyde 3-phosphate dehydrogenase $(74,124)$.

\section{Cysteine lowers advanced glycation end products}

Insulin resistance and impaired glucose metabolism can result in an accumulation of reactive aldehydes, including methylglyoxal and glyoxal. These aldehydes react with free $\mathrm{SH}$ and amino groups of proteins and DNA to form advanced glycation end products (AGEs) $(48,125-128)$. These structural changes alter protein function $(65,129-134)$. AGEs may also interact with membrane receptors, including receptors of AGEs (RAGEs) and scavenger receptors, to alter cell function $(135,136)$. Oxidative stress has also been shown to increase aldehyde and AGE formation $(137,138)$.

Methylglyoxal and glyoxal are normally maintained at a low level because they are catabolized via the glutathionedependent glyoxalase enzyme system. Thiols such as cysteine also bind these aldehydes, allowing them to be excreted in bile and urine $(48,139)$. Like ROS, at low levels, AGEs may have normal physiological roles (140). However, when AGE levels increase, there may be pathological consequences. A growing body of evidence implicates AGEs in the development of hypertension $(16,23,30,141-147)$. Cells exposed to aldehydes or AGEs show an increase in intracellular ROS (147-150), changes in calcium handling $(66,135)$, altered cell signalling with increased transcription of inflammatory proteins and production of vasoconstricting agents (150-154), and VSMC proliferation $(155,156)$. Rats treated with methylglyoxal develop an increase in tissue AGEs, platelet cytosolic free calcium and blood pressure, as well as adverse renal vascular changes (157). Additionally, methylglyoxal and AGEs are increased in both genetic and diet-induced rat models of hypertension $(16,23,30,141-144,146)$. Although there is increasing evidence of a role for AGEs in animal models of hypertension, there are few studies in humans. One study of hypertensive patients showed an elevation in plasma AGEs in association with increased vascular stiffness (158). Another study in diabetic patients showed that those with hypertension had higher plasma AGE levels than their normotensive counterparts (159). Aldehydes and AGEs have also been shown to inhibit glycolytic enzymes $(65,134,160)$, alter insulin function (132) and impair insulin signalling $(130,131)$, as well as inhibit antioxidant enzymes $(65,129)$, thus perpetuating the cycle of insulin resistance and oxidative stress.

Cysteine may attenuate hypertension by boosting GSHdependent catabolism and excretion of reactive aldehydes, thereby preventing AGE formation and the subsequent downstream effects. Most of the research on cysteine and AGEs has focused on their ability to prevent insulin resistance, although some studies have investigated their effect on oxidative stress, intracellular calcium levels or cell signalling. Unoki et al (161) demonstrated that AGE-RAGE interaction increased intracellular oxidative stress, causing a decrease in glucose uptake in cultured 3T3-L1 adipocytes. This effect was completely reversed by treatment with NAC. AGE-RAGE binding caused an increase in oxidative stress and AII production in rat mesangial cells that was prevented by addition of NAC (153). NAC attenuated a methylglyoxal-induced increase in the transcription factor nuclear factor kappa B and prevented an increase in GSSG in the VSMC of SHRs (147). Jia and Wu (131) showed that methylglyoxal decreased insulin-induced IRS-1 tyrosine phosphorylation and decreased kinase activity of PI3K to impair insulin signalling in cultured 3T3-L1 adipocytes. This impairment was prevented by the addition of NAC to the cell culture. These authors also demonstrated that $10 \mathrm{mg} / \mathrm{kg} \mathrm{bw} /$ day of NAC given to fructose-fed SD rats in drinking water for nine weeks prevented an increase in serum and adipose tissue methylglyoxal levels, and improved glucose uptake (131). Coinfusion of NAC with high amounts of glucose in SD rats prevented sugar-induced insulin resistance and lowered carbonyl content in soleus muscles (162). Supplementation with NAC decreased tissue AGEs, plasma glucose, platelet cytosolic free calcium and blood pressure in fructose-fed WKY rats (30). Similarly, in SHRs, NAC treatment lowered tissue AGEs, platelet cytosolic free calcium and blood pressure (23). These data from in vitro and in vivo experiments demonstrate that NAC lowers aldehydes and AGEs, improves insulin resistance, reduces oxidative stress and lowers cytosolic free calcium.

\section{Cysteine improves bioavailability of NO and endothelial function}

One of the major regulators of blood pressure is NO. The enzyme NOS catalyzes the conversion of arginine to NO in the presence of various cofactors. Endothelium-derived NO activates guanylate cyclase to generate cyclic guanosine monophosphate, resulting in VSMC relaxation and vasodilation, thus contributing to the regulation of peripheral blood flow, vascular resistance and blood pressure. eNOS expression and $\mathrm{NO}$ formation also result from receptor-mediated stimulation of the IRS/PI3K/Akt/eNOS insulin signalling pathway; thus, their levels are partially regulated by insulin (99-102). NO not only regulates blood pressure but maintains other aspects of vascular health by inhibiting platelet aggregation, VSMC migration and proliferation, and adhesion molecule expression and monocyte adhesion (163). Abnormalities in NO bioavailability may therefore result in inflammation, increased cell proliferation, altered vascular reactivity and elevations in blood pressure.

In humans with essential hypertension, decreased synthesis of endothelium-derived NO partly accounts for both the increase in vascular resistance and the impaired response to endothelium-dependent vasodilation (9-11,164). In animal models of hypertension including SHRs, and fructose- and saltinduced hypertensive rats, $\mathrm{NO}$ production by resistance arteries is impaired (165-167). In the insulin-resistant state in both humans and animals, abnormalities in insulin-induced $\mathrm{NO}$ synthesis via the IRS/PI3K/Akt/eNOS pathway may contribute to altered vascular function and hypertension $(102,119,120,168)$.

Oxidative breakdown of $\mathrm{NO}$ gives rise to radicals such as $\mathrm{O}_{2}{ }^{-}$, peroxynitrite and peroxynitrous acid (169), not only decreasing $\mathrm{NO}$ levels but increasing oxidative stress. An increased production of $\mathrm{O}_{2}^{-}$by NADPH oxidase in association with diminished NO generation was found in hypertensive subjects (7). Oxidative stress has been shown to cause 'uncoupling' 
of eNOS, disabling the enzyme, producing $\mathrm{O}_{2}{ }^{-}$and limiting NO formation $(80,170)$. eNOS contains a free cysteine $\mathrm{SH}$ group at its catalytic site, making it susceptible to inactivation by ROS and aldehydes (43). ROS also interfere with signalling via the IRS/PI3K/Akt/eNOS pathway (79), which may result in altered NOS expression and decreased $\mathrm{NO}$ production.

As major endogenous antioxidants, cysteine and GSH protect NO, NOS and signalling pathways from the oxidative effects of ROS, thereby preserving NO bioavailability. A study by Ramasamy et al (171) showed that NAC increased eNOS expression and activity in both bovine and human endothelial cells in culture. This effect of NAC was further demonstrated by a study in which addition of NAC to tumour necrosis factoralpha-treated human vascular endothelial cells in culture restored eNOS expression and increased NO production (172). Supplementation with $1.44 \mathrm{~g} / \mathrm{kg}$ bw/day of NAC in drinking water for eight weeks in type 1 diabetic rats increased myocardial eNOS protein expression and plasma nitrate/nitrite, a marker of $\mathrm{NO}$ production, concomitantly with a reduction in oxidative stress (173). In this same rat model, $55 \mathrm{mg} /$ day of NAC in drinking water for eight weeks normalized endothelium-dependent vasodilation in the aorta (174). In SHRs, NAC treatment improved peroxynitrite-induced impairments in endotheliumdependent vasodilation in the aorta (24). NAC treatment also normalized impaired endothelium-dependent vasodilation in the renal arteries of high salt-treated DSS rats (27). In patients undergoing cardiac catheterization, intra-arterial NAC improved coronary and peripheral endothelium-dependent vasodilation (175), consistent with a preservation of NO function. Contrary to these results with NAC, a methionineenriched diet impaired endothelium-dependent vasodilation in WKY control rats, consistent with the increase in blood pressure seen in these animals, indicating impaired bioavailability of NO (35). This may be due to incomplete metabolism of methionine to cysteine as illustrated by the increase in homocysteine levels. In SHRs, endothelium-dependent vasodilation was also impaired by methionine. However, this was not in agreement with the decrease in blood pressure seen in this model. It was suggested that the hypertensive consequence of methionine supplementation was masked by some other unexplained antihypertensive mechanism in these animals.

Cysteine and glutathione were shown to prevent inhibition of NOS by ebselen, a seleno-organic compound, by providing a competing source of free SH groups (176). In L-NAME-treated Wistar rats, NAC treatment increased NOS activity in the left ventricle and kidney (32). NAC treatment in SHRs also increased NOS activity in the left ventricle and kidney, and enhanced eNOS protein expression in the left ventricle (26). In another study of SHRs, NAC improved L-NAME-induced impairment in endothelium-dependent vasodilation, suggesting that NAC compensates for the loss of NO (33).

Both cysteine and glutathione react with $\mathrm{NO}$ via their $\mathrm{SH}$ groups to form SNOs, molecules that are more stable than NO itself. S-nitrosocysteine gives up its $\mathrm{NO}$ more readily than S-nitrosoglutathione $(49,53)$, and both serve as part of a transnitrosation system that ferries $\mathrm{NO}$ to and from large $\mathrm{SH}$-containing proteins such as albumin (49-51). In the form of $\mathrm{S}$-nitrosoalbumin, $\mathrm{NO}$ is even more stable $(49,51)$. Initially, it was thought that SNOs were simple carriers of NO that passively released NO for diffusion into the cell. Subsequently, it has been shown that NO release may also be initiated by the reaction of SNOs with ions such as copper $(177,178)$, enzymes including thioredoxin reductase (179) and alcohol dehydrogenase (180), or through reaction with membrane thiols (181). Although extending the half-life of NO may indeed be one of the functions and mechanisms of action of SNOs, it has been shown repeatedly that the amount of $\mathrm{NO}$ released does not sufficiently account for their total biological activity $(52,53,182)$. It appears that cysteine and glutathione in the form of $\mathrm{SNOs}$ likely play a multifaceted role in the complex biology of NO through independent vasoactive properties, transnitrosation reactions, and the balance between their synthesis and degradation $(49,52-55)$.

SNOs have vasoactivity independent of their $\mathrm{NO}$ content, and are known to stimulate guanylate cyclase, promote vascular relaxation, reduce platelet aggregation and lower blood pressure $(50-53,55,183,184)$. It has been suggested that S-nitrosocysteine may act via stereoselective membrane-bound receptors $(185,186)$ or through transnitrosation reactions with membrane-bound thiols (181). Scharfstein et al (51) illustrated the potential importance of transnitrosation in the vasoactive biology of SNOs by demonstrating that the vascular sensitivity to $\mathrm{S}$-nitrosoalbumin was enhanced 18 -fold by preinfusion of cysteine and threefold by preinfusion of NAC. Another study by Zhang and Hogg (187) also demonstrated this relationship in macrophages. In that study, the presence of cystine (cysteine's redox partner) enhanced cellular uptake of SNO, likely via conversion of cystine to cysteine. This was followed by a transfer of NO from S-nitrosoglutathione to cysteine and subsequent transfer of S-nitrosocysteine to the cytosol via membrane arginine transporters. The stability and rate of decomposition of SNOs may depend on their individual concentrations in circulation, as well as those of other coexisting thiols and SNOs (53). It has been shown that the presence of cysteine decreases the stability of S-nitrosoglutathione, while GSH increases the stability of S-nitrosocysteine, indicating the interactive relationship of these compounds and the potential impact of changes in thiol concentrations on hemodynamic regulation. Because $\mathrm{NO}$ is considered to be an intracellular signalling molecule (188), the transnitrosation properties of cysteine and GSH make them potentially important regulators of intracellular functions, such as movement of calcium $(67,189)$, gene transcription and protein expression $(190,191)$, and glucose metabolism (192). In summary, cysteine and glutathione regulate vascular function by protecting NO, NOS and insulin signalling pathways from alteration by ROS. They also act directly on vasculature and participate in the complex biology of $\mathrm{NO}$ in the form of SNOs.

\section{Cysteine modulates other vasoactive systems}

Another major system involved in blood pressure control is counter-regulatory to the NO pathway. The renin-angiotensin system (RAS) controls vascular tone by converting angiotensin I to the vasoconstrictor AII via ACE. AII acts on membrane receptors in vascular tissue causing vasoconstriction. It also triggers the release of aldosterone to increase renal sodium and water retention.

Although AII infusion has been shown to increase blood pressure in animal models (193), there does not appear to be strong evidence implicating defects in the RAS as a primary 
etiological mechanism in essential hypertension in humans. It may be that alterations in RAS occur secondarily as a consequence of oxidative stress $(62,72)$, elevated AGEs $(153,194)$, high insulin concentrations $(103,104,195)$ and decreased NO (196). Once activated, the RAS can contribute to insulin resistance, and increase blood pressure, oxidative stress and cell proliferation (193,197-201).

Cysteine and GSH may contribute to blood pressure control and endothelial function by modulating the RAS. In vitro experiments have demonstrated that exposure of the kidneys, heart and brain to oxidizing agents increases ACE activity $(62,72)$, and NAC and glutathione inhibit this increase when applied to the kidney cortex (62). AGE-RAGE interactions increased AII via an ROS-mediated mechanism in mesangial cells in vitro, and these changes were prevented by NAC treatment (153). It has been suggested that AII may contribute to insulin resistance because it inhibits insulin signalling in aortic VSMCs (197). Taniyama et al (78) showed that AII decreased IRS-1 protein levels in these cells by an ROS-mediated mechanism. This effect was prevented by the addition of NAC. A study by Boesgaard et al (202) showed that intravenous infusion of NAC, $5 \mathrm{mmol} / \mathrm{kg} \mathrm{bw} / \mathrm{h}$ for $3 \mathrm{~h}$ in Wistar rats, resulted in a decrease in the pressor effect of an intravenous infusion of angiotensin, and a reduction in plasma and kidney ACE activity. NAC infusion also decreased an earlier isosorbide dinitrate-induced increase in AII in human subjects (202). Because ROS stimulate ACE activity (62) and act as second messengers in many AII-mediated pathways (203), it is likely that cysteine and GSH moderate the vasoconstrictor effects of the RAS mainly via their antioxidant properties. However, an additional mechanism of action has been suggested in another study using VSMCs in vitro. In that study, the addition of NAC and other thiol-containing antioxidants lowered AII binding to AII type 1 receptors (204). Considering that the effect was not seen using nonthiol antioxidants or oxidized NAC, it was suggested that it involved a direct reaction of NAC with the disulfide bonds of the receptor.

In recent years, there has been growing interest in another potential contributor to vascular tone, $\mathrm{H}_{2} \mathrm{~S}$. The production of $\mathrm{H}_{2} \mathrm{~S}$ from cysteine is catalyzed by cystathionine gammalyase (CSE) and cystathionine beta-synthase, two vitamin $\mathrm{B}_{6}$-dependent enzymes involved in the methionine catabolism pathway (205) (Figure 2). At higher concentrations, $\mathrm{H}_{2} \mathrm{~S}$ causes vascular relaxation in precontracted human mammary arteries (206) and rat aortas (207), and is mediated by the opening of ATP-dependent potassium channels (206). However, at lower concentrations, it causes vascular contraction in these arteries. Infusion of a low concentration of $\mathrm{H}_{2} \mathrm{~S}$ concurrently with an $\mathrm{NO}$ donor results in inhibition of the vasodilator effect of $\mathrm{NO}$ (207), suggesting that the contractile action of $\mathrm{H}_{2} \mathrm{~S}$ is produced via an NO-mediated effect, possibly through the formation of an inactive nitrosothiol. This finding was confirmed in vivo in a rat model (207). This interrelationship suggests there may be cross-talk between $\mathrm{H}_{2} \mathrm{~S}$ and $\mathrm{NO}(207,208)$. Thus, the physiological role for $\mathrm{H}_{2} \mathrm{~S}$, although still unclear, may partially involve regulation of $\mathrm{NO}$ and vice versa. The role of $\mathrm{H}_{2} \mathrm{~S}$ in hypertension also remains to be ascertained. Plasma $\mathrm{H}_{2} \mathrm{~S}$ levels are low in SHRs (209) and L-NAME-induced hypertensive rats (208), as well as in children with hypertension (210). In L-NAME-induced hypertensive rats, $\mathrm{H}_{2} \mathrm{~S}$ generation is reduced and CSE gene expression is decreased, suggesting that $\mathrm{NO}$ may control $\mathrm{H}_{2} \mathrm{~S}$ generation at the gene level. In these hypertensive animal models in which plasma levels of $\mathrm{H}_{2} \mathrm{~S}$ are low, administration of an exogenous $\mathrm{H}_{2} \mathrm{~S}$ donor, $\mathrm{NaHS}$, lowers blood pressure (208). In hypertension, it may be that low NO levels result in reduced expression of CSE with a subsequent decrease in $\mathrm{H}_{2} \mathrm{~S}$ production, lowering plasma concentrations and increasing vascular contraction. Alternately, it may be that an increase in oxidative stress with an ensuing depletion of cysteine limits $\mathrm{H}_{2} \mathrm{~S}$ production. Because there is a dearth of research on the role of $\mathrm{H}_{2} \mathrm{~S}$ in hypertension, these explanations are purely speculative. Certainly, much more research needs to be performed in this area to determine the role of cysteine and/or glutathione in the actions of $\mathrm{H}_{2} \mathrm{~S}$ on blood pressure.

\section{Cysteine improves renal function}

Under normal conditions, the kidneys are key regulators of blood pressure homeostasis; they control blood volume through regulation of sodium excretion and reabsorption. Hypertension itself is a risk factor for developing renal disease (211), as documented by the United States renal disease registry database (212), which lists hypertension as the cause of approximately one-quarter of end-stage renal disease cases from 2000 to 2004. However, changes to kidney function can also cause an increase in blood pressure. This fact is evident in patients with moderate to severe renal disease who experience a very high incidence of hypertension (213). In essential hypertension, the independent, collective or interactive effects of insulin resistance, activation of RAS, decreased NO, or increased oxidative stress and AGEs on the kidneys may contribute to a decrease in kidney function, leading to elevations in blood pressure $(27,28,82,83,214-218)$. If the systemic effects of NAC to normalize or attenuate these alterations lower blood pressure (as previously discussed), this would prevent consequent pressureinduced damage to kidney tissue. Alternatively, if cysteine counteracts the direct pathological effects of these alterations on the kidneys, preserving renal function, this may partially explain its antihypertensive effect. It is probable that cysteine offers renal protection by both means.

Prehypertensive SHRs showed increased oxidative stress and inflammation in the kidneys that was attenuated by treatment with NAC (82). Hypertensive SHRs and fructoseinduced hypertensive rats both demonstrated an increase in kidney AGEs and renal vascular proliferation in conjunction with elevated blood pressures that were reduced by NAC treatment $(23,30)$. In DSS rats, a high-salt diet increased renal oxidative stress and blood pressure, while addition of NAC normalized blood pressure and reduced oxidative stress to preserve kidney function (28). Another study in DSS rats showed that NAC lowered blood pressure, ameliorated renal oxidative stress, improved impaired endothelial-dependent vasodilation in the renal artery and normalized renal function (27). This suggests a mechanism of action by NAC that reduces oxidative stress, thereby preventing breakdown of $\mathrm{NO}$ in the kidneys to preserve renal function. This renal-protective effect of NAC was also demonstrated in partially nephrectomized Wistar rats, in which NAC treatment lowered blood pressure, decreased oxidative stress, improved renal function and attenuated the progression to chronic renal failure (219). In a study of renal 
microcirculation in SD rats subjected to intravenous vasoconstriction agents, infusion of NAC improved blood flow and lowered vascular resistance by a mechanism other than $\mathrm{NO}$ or prostaglandins (220). It is clear that cysteine offers renal protection that may prevent progression to hypertension. As well, it ameliorates changes to the kidneys brought on by hypertension.

\section{CONCLUSIONS}

Cysteine and its endogenous storage form, glutathione, are involved in vasoregulatory processes and play a significant role in modulating hypertension. They are important antioxidants that participate in controlling oxidative stress. These thiols improve insulin resistance and lower AGEs, increase bioavailable $\mathrm{NO}$ and, in the form of nitrosothiols, participate in the complex biology of NO. They may also be involved in other vasoregulatory systems such as the RAS and $\mathrm{H}_{2} \mathrm{~S}$ pathway, and provide renal-protective effects. NAC supplementation lowers blood pressure in genetic and salt-, sugar- or L-NAME-induced rat models of hypertension. NAC has been safely used as a complement to traditional antihypertensive therapies to lower blood pressures in humans. However, there are no studies in humans in which it has been used alone. Therefore, at present, dietary intake of protein may be the appropriate way to achieve an adequate intake of cysteine. Adopting a diet containing ample amounts of protein and antioxidant vitamins, such as the DASH diet - which is rich in vegetables, fruits and low-fat dairy products, low in salt and saturated fat, and includes whole grains, poultry, fish and nuts - may be a safe and realistic means for individuals with hypertension to have an appropriate cysteine intake.

ACKNOWLEDGEMENTS: The authors thank the Canadian Institutes of Health Research Regional Partnership Program and the Discipline of Medicine, Memorial University, St John's, Newfoundland, for financial support. Dr Singal is the holder of the Naranjan S Dhalla Chair in Cardiovascular Research supported by the St Boniface Hospital and Research Foundation.

\section{REFERENCES}

1. World Health Organization. Global strategy on diet, physical activity and health. Chronic disease risk factors. <www.who.int/ dietphysicalactivity/publications/facts/riskfactors/en> (Version current at May 1, 2009).

2. Ferrannini E, Buzzigoli G, Bonadonna R, et al. Insulin resistance in essential hypertension. N Engl J Med 1987;317:350-7.

3. Reaven GM. Insulin resistance, hyperinsulinemia, and hypertriglyceridemia in the etiology and clinical course of hypertension. Am J Med 1991;90:7S-12S.

4. Sagar S, Kallo IJ, Kaul N, Ganguly NK, Sharma BK. Oxygen free radicals in essential hypertension. Mol Cell Biochem 1992;111:103-8.

5. Kumar KV, Das UN. Are free radicals involved in the pathobiology of human essential hypertension? Free Radic Res Commun 1993;19:59-66.

6. Tandon R, Sinha MK, Garg H, Khanna R, Khanna HD. Oxidative stress in patients with essential hypertension. Natl Med J India 2005;18:297-9.

7. Fortuno A, Olivan S, Beloqui O, et al. Association of increased phagocytic NADPH oxidase-dependent superoxide production with diminished nitric oxide generation in essential hypertension. J Hypertens 2004;22:2169-75.

8. Prabha PS, Das UN, Koratkar R, Sagar PS, Ramesh G. Free radical generation, lipid peroxidation and essential fatty acids in uncontrolled essential hypertension. Prostaglandins Leukot Essent Fatty Acids 1990;41:27-33.

9. Panza JA, Casino PR, Kilcoyne CM, Quyyumi AA. Role of endothelium-derived nitric oxide in the abnormal endotheliumdependent vascular relaxation of patients with essential hypertension. Circulation 1993;87:1468-74.

10. Panza JA, Garcia CE, Kilcoyne CM, Quyyumi AA, Cannon RO III. Impaired endothelium-dependent vasodilation in patients with essential hypertension. Evidence that nitric oxide abnormality is not localized to a single signal transduction pathway. Circulation 1995;91:1732-8.

11. Taddei S, Virdis A, Ghiadoni L, Salvetti G, Salvetti A. Endothelial dysfunction in hypertension. J Nephrol 2000;13:205-10.

12. Vasdev S, Gill V. Antioxidants in the treatment of hypertension. Int J Angiol 2005;14:60-73.

13. Sacks FM, Svetkey LP, Vollmer WM, et al; DASH-Sodium Collaborative Research Group. Effects on blood pressure of reduced dietary sodium and the dietary approaches to stop hypertension (DASH) diet. DASH-sodium collaborative research group. N Engl J Med 2001;344:3-10.

14. Rebello T, Hodges RE, Smith JL. Short-term effects of various sugars on antinatriuresis and blood pressure changes in normotensive young men. Am J Clin Nutr 1983;38:84-94.

15. Hodges RE, Rebello T. Carbohydrates and blood pressure. Ann Intern Med 1983;98:838-41.

16. Vasdev S, Gill V, Longerich L, Parai S, Gadag V. Salt-induced hypertension in WKY rats: Prevention by alpha-lipoic acid supplementation. Mol Cell Biochem 2003;254:319-26.

17. Vasdev S, Ford CA, Parai S, Longerich L, Gadag V. Dietary lipoic acid supplementation prevents fructose-induced hypertension in rats. Nutr Metab Cardiovasc Dis 2000;10:339-46.

18. Appel LJ, Moore TJ, Obarzanek E, et al. A clinical trial of the effects of dietary patterns on blood pressure. DASH collaborative research group. N Engl J Med 1997;336:1117-24.

19. Appel LJ, Sacks FM, Carey VJ, et al; OmniHeart Collaborative Research Group. Effects of protein, monounsaturated fat, and carbohydrate intake on blood pressure and serum lipids: Results of the OmniHeart randomized trial. JAMA 2005;294:2455-64.

20. Stamler J, Caggiula A, Grandits GA, Kjelsberg M, Cutler JA. Relationship to blood pressure of combinations of dietary macronutrients. Findings of the multiple risk factor intervention trial (MRFIT). Circulation 1996;94:2417-23.

21. Stamler J, Elliott P, Kesteloot H, et al. Inverse relation of dietary protein markers with blood pressure. Findings for 10,020 men and women in the INTERSALT study. INTERSALT cooperative research group. INTERnational study of SALT and blood pressure. Circulation 1996;94:1629-34.

22. Ruiz FJ, Salom MG, Ingles AC, Quesada T, Vicente E, Carbonell LF. N-acetyl-L-cysteine potentiates depressor response to captopril and enalaprilat in SHRs. Am J Physiol 1994;267:R767-72.

23. Vasdev S, Mian T, Ford CA, Longerich L, Parai S. Role of endogenous aldehydes in spontaneously hypertensive and disulfiram-induced hypertensive rats. Nutr Metab Cardiovasc Dis 1996;6:130-40.

24. Cabassi A, Dumont EC, Girouard H, et al. Effects of chronic $\mathrm{N}$-acetylcysteine treatment on the actions of peroxynitrite on aortic vascular reactivity in hypertensive rats. J Hypertens 2001;19:1233-44.

25. Girouard H, Chulak C, Wu L, Lejossec M, de Champlain J. $\mathrm{N}$-acetylcysteine improves nitric oxide and alpha-adrenergic pathways in mesenteric beds of spontaneously hypertensive rats. Am J Hypertens 2003;16:577-84.

26. Pechanova O, Zicha J, Kojsova S, Dobesova Z, Jendekova L, Kunes J. Effect of chronic $\mathrm{N}$-acetylcysteine treatment on the development of spontaneous hypertension. Clin Sci (Lond) 2006;110:235-42.

27. Zhang L, Fujii S, Igarashi J, Kosaka H. Effects of thiol antioxidant on reduced nicotinamide adenine dinucleotide phosphate oxidase in hypertensive Dahl salt-sensitive rats. Free Radic Biol Med 2004;37:1813-20. 
28. Tian N, Rose RA, Jordan S, Dwyer TM, Hughson MD, Manning RD Jr. N-acetylcysteine improves renal dysfunction, ameliorates kidney damage and decreases blood pressure in salt-sensitive hypertension. J Hypertens 2006;24:2263-70.

29. Kunes J, Dobesova Z, Zicha J. Chronic N-acetylcysteine treatment prevents the development of salt hypertension in immature Dahl rats. J Hypertension Supp 2004;22:153. (Abst)

30. Vasdev S, Ford CA, Longerich L, Gadag V, Wadhawan S. Role of aldehydes in fructose induced hypertension. Mol Cell Biochem 1998;181:1-9.

31. Song D, Hutchings S, Pang CC. Chronic N-acetylcysteine prevents fructose-induced insulin resistance and hypertension in rats. Eur J Pharmacol 2005;508:205-10.

32. Rauchova H, Pechanova O, Kunes J, Vokurkova M, Dobesova Z, Zicha J. Chronic $\mathrm{N}$-acetylcysteine administration prevents development of hypertension in N(omega)-nitro-L-arginine methyl ester-treated rats: The role of reactive oxygen species. Hypertens Res 2005;28:475-82.

33. Zicha J, Dobesova Z, Kunes J. Antihypertensive mechanisms of chronic captopril or N-acetylcysteine treatment in L-NAME hypertensive rats. Hypertens Res 2006;29:1021-7.

34. Ciaccio M, Bivona G, Bellia C. Therapeutical approach to plasma homocysteine and cardiovascular risk reduction. Ther Clin Risk Manag 2008;4:219-24.

35. Robin S, Maupoil V, Groubatch F, Laurant P, Jacqueson A, Berthelot A. Effect of a methionine-supplemented diet on the blood pressure of wistar-kyoto and spontaneously hypertensive rats. Br J Nutr 2003;89:539-48.

36. Mariotti F, Hammiche A, Blouet C, Dare S, Tome D, Huneau JF. Medium-term methionine supplementation increases plasma homocysteine but not ADMA and improves blood pressure control in rats fed a diet rich in protein and adequate in folate and choline. Eur J Nutr 2006;45:383-90.

37. Robin S, Maupoil V, Laurant P, Jacqueson A, Berthelot A. Effect of a methionine-supplemented diet on the blood pressure of SpragueDawley and deoxycorticosterone acetate-salt hypertensive rats. Br J Nutr 2004;91:857-65.

38. Suarez C, del Arco C, Lahera V, Ruilope LM. N-acetylcysteine potentiates the antihypertensive effect of angiotensin converting enzyme inhibitors. Am J Hypertens 1995;8:859.

39. Barrios V, Calderon A, Navarro-Cid J, Lahera V, Ruilope LM. $\mathrm{N}$-acetylcysteine potentiates the antihypertensive effect of ACE inhibitors in hypertensive patients. Blood Press 2002;11:235-9.

40. Martina V, Masha A, Gigliardi VR, et al. Long-term $\mathrm{N}$-acetylcysteine and $\mathrm{L}$-arginine administration reduces endothelial activation and systolic blood pressure in hypertensive patients with type 2 diabetes. Diabetes Care 2008;31:940-4.

41. Pennington JA. Supplementary tables - amino acids. In: Allen A, ed. Bowes \& Church's Food Values of Portions Commonly Used, 16th edn. Philadelphia: JB Lippincott Company, 1994:A325-77.

42. Rodwell VW. Proteins: Structure and function. In: Murray RK, Granner DK, Mayes PA, Rodwell VW, eds. Harper's Biochemistry, 24th edn. Stamford: Appleton \& Lange, 1996:41-51.

43. Chen PF, Tsai AL, Wu KK. Cysteine 184 of endothelial nitric oxide synthase is involved in heme coordination and catalytic activity. J Biol Chem 1994;269:25062-6.

44. May JM, Qu Z, Li X. Requirement for GSH in recycling of ascorbic acid in endothelial cells. Biochem Pharmacol 2001;62:873-81.

45. May JM, Qu ZC, Neel DR, Li X. Recycling of vitamin C from its oxidized forms by human endothelial cells. Biochim Biophys Acta 2003;1640:153-61.

46. Ho CT, Chan AC. Regeneration of vitamin E in rat polymorphonuclear leucocytes. FEBS Lett 1992;306:269-72.

47. Thornalley PJ. Modification of the glyoxalase system in disease processes and prospects for therapeutic strategies. Biochem Soc Trans 1993;21:531-4.

48. Schauenstein E, Esterbauer H, Zollner H. Aldehydes in biological systems. In: Lagnado JR, ed. Aldehydes in Biological Systems: Their Natural Occurrence and Biological Activities. London: Pion Limited, 1977:1-7.

49. Jourd'heuil D, Hallen K, Feelisch M, Grisham MB. Dynamic state of S-nitrosothiols in human plasma and whole blood. Free Radic Biol Med 2000;28:409-17.

50. Stamler JS, Simon DI, Osborne JA, et al. S-nitrosylation of proteins with nitric oxide: Synthesis and characterization of biologically active compounds. Proc Natl Acad Sci USA 1992;89:444-8.
51. Scharfstein JS, Keaney JF Jr, Slivka A, et al. In vivo transfer of nitric oxide between a plasma protein-bound reservoir and low molecular weight thiols. J Clin Invest 1994;94:1432-9.

52. Mathews WR, Kerr SW. Biological activity of S-nitrosothiols: The role of nitric oxide. J Pharmacol Exp Ther 1993;267:1529-37.

53. Tullett JM, Rees DD, Shuker DE, Gescher A. Lack of correlation between the observed stability and pharmacological properties of S-nitroso derivatives of glutathione and cysteine-related peptides. Biochem Pharmacol 2001;62:1239-47.

54. Park JW, Billman GE, Means GE. Transnitrosation as a predominant mechanism in the hypotensive effect of S-nitrosoglutathione. Biochem Mol Biol Int 1993;30:885-91.

55. Stuesse DC, Giraud GD, Vlessis AA, Starr A, Trunkey DD. Hemodynamic effects of S-nitrosocysteine, an intravenous regional vasodilator. J Thorac Cardiovasc Surg 2001;122:371-7.

56. Fajans SS, Floyd JC Jr, Knopf RF, Conn FW. Effect of amino acids and proteins on insulin secretion in man. Recent Prog Horm Res 1967;23:617-62.

57. Lavis VR, Williams RH. Studies of the insulin-like actions of thiols upon isolated fat cells. J Biol Chem 1970;245:23-31.

58. Gazit V, Ben-Abraham R, Vofsi O, Katz Y. L-cysteine increases glucose uptake in mouse soleus muscle and SH-SY5Y cells. Metab Brain Dis 2003;18:221-31.

59. Zaidi NF, Lagenaur CF, Abramson JJ, Pessah I, Salama G. Reactive disulfides trigger $\mathrm{Ca}^{2+}$ release from sarcoplasmic reticulum via an oxidation reaction. J Biol Chem 1989;264:21725-36.

60. Tabet F, Savoia C, Schiffrin EL, Touyz RM. Differential calcium regulation by hydrogen peroxide and superoxide in vascular smooth muscle cells from spontaneously hypertensive rats. J Cardiovasc Pharmacol 2004:44:200-8.

61. Suzuki YJ, Ford GD. Inhibition of $\mathrm{Ca}(2+)$-ATPase of vascular smooth muscle sarcoplasmic reticulum by reactive oxygen intermediates. Am J Physiol 1991;261:H568-74.

62. Ikemoto F, Song G, Tominaga M, Yamamoto K. Oxidation-induced increase in activity of angiotensin converting enzyme in the rat kidney. Biochem Biophys Res Commun 1988;153:1032-7.

63. Lopez BE, Wink DA, Fukuto JM. The inhibition of glyceraldehyde3-phosphate dehydrogenase by nitroxyl (HNO). Arch Biochem Biophys 2007;465:430-6.

64. Drummond GR, Cai H, Davis ME, Ramasamy S, Harrison DG. Transcriptional and posttranscriptional regulation of endothelial nitric oxide synthase expression by hydrogen peroxide. Circ Res 2000;86:347-54.

65. Morgan PE, Dean RT, Davies MJ. Inactivation of cellular enzymes by carbonyls and protein-bound glycation/glycoxidation products. Arch Biochem Biophys 2002;403:259-69.

66. Jan CR, Chen CH, Wang SC, Kuo SY. Effect of methylglyoxal on intracellular calcium levels and viability in renal tubular cells. Cell Signal 2005;17:847-55.

67. Palmerini CA, Mazzoni M, Saccardi C, Arienti G. The cytosolic calcium concentration is affected by S-nitrosocysteine in human lymphomonocytes. J Biochem Mol Toxicol 2008;22:35-40.

68. Demirkol O, Adams C, Ercal N. Biologically important thiols in various vegetables and fruits. J Agric Food Chem 2004;52:8151-4.

69. Pechanova O, Zicha J, Paulis L, et al. The effect of $\mathrm{N}$-acetylcysteine and melatonin in adult spontaneously hypertensive rats with established hypertension. Eur J Pharmacol 2007;561:129-36.

70. Beckman JS, Koppenol WH. Nitric oxide, superoxide, and peroxynitrite: The good, the bad, and ugly. Am J Physiol 1996;271:C1424-37.

71. Griendling KK, Sorescu D, Ushio-Fukai M. NAD(P)H oxidase: Role in cardiovascular biology and disease. Circ Res 2000;86:494-501.

72. Tominaga M, Song GB, Ikemoto F, Yamamoto K. Effect of oxidation on the activity of angiotensin converting enzyme in the rat kidney, heart and brain. Clin Exp Hypertens A 1988; $10: 1271-8$.

73. Janero DR, Hreniuk D, Sharif HM. Hydroperoxide-induced oxidative stress impairs heart muscle cell carbohydrate metabolism. Am J Physiol 1994;266:C179-88.

74. Schulpis KH, Reclos GJ, Parthimos T, Parthimos N, Gavriilidis A, Tsakiris S. L-cysteine supplementation protects the erythrocyte glucose-6-phosphate dehydrogenase activity from reduction induced by forced training. Clin Biochem 2006;39:1002-6. 
75. Chiarugi P, Cirri P. Redox regulation of protein tyrosine phosphatases during receptor tyrosine kinase signal transduction. Trends Biochem Sci 2003;28:509-14.

76. Suzuki YJ, Ford GD. Redox regulation of signal transduction in cardiac and smooth muscle. J Mol Cell Cardiol 1999;31:345-53.

77. Nakashima I, Takeda K, Kawamoto Y, Okuno Y, Kato M, Suzuki H. Redox control of catalytic activities of membrane-associated protein tyrosine kinases. Arch Biochem Biophys 2005;434:3-10.

78. Taniyama Y, Hitomi H, Shah A, Alexander RW, Griendling KK. Mechanisms of reactive oxygen species-dependent downregulation of insulin receptor substrate-1 by angiotensin II. Arterioscler Thromb Vasc Biol 2005;25:1142-7.

79. Gardner CD, Eguchi S, Reynolds CM, Eguchi K, Frank GD, Motley ED. Hydrogen peroxide inhibits insulin signaling in vascular smooth muscle cells. Exp Biol Med (Maywood) 2003;228:836-42.

80. Landmesser U, Dikalov S, Price SR, et al. Oxidation of tetrahydrobiopterin leads to uncoupling of endothelial cell nitric oxide synthase in hypertension. J Clin Invest 2003;111:1201-9.

81. Suzuki YJ, Ford GD. Superoxide stimulates IP3-induced $\mathrm{Ca}^{2+}$ release from vascular smooth muscle sarcoplasmic reticulum. Am J Physiol 1992;262:H114-6.

82. Biswas SK, de Faria JB. Which comes first: Renal inflammation or oxidative stress in spontaneously hypertensive rats? Free Radic Res 2007;41:216-24.

83. Trolliet MR, Rudd MA, Loscalzo J. Oxidative stress and renal dysfunction in salt-sensitive hypertension. Kidney Blood Press Res 2001;24:116-23.

84. Janero DR, Burghardt B. Cardiac membrane vitamin E and malondialdehyde levels in heart muscle of normotensive and spontaneously-hypertensive rats. Lipids 1989;24:33-8.

85. Diniz YS, Rocha KK, Souza GA, et al. Effects of N-acetylcysteine on sucrose-rich diet-induced hyperglycaemia, dyslipidemia and oxidative stress in rats. Eur J Pharmacol 2006;543:151-7.

86. Blouet C, Mariotti F, Azzout-Marniche D, et al. Dietary cysteine alleviates sucrose-induced oxidative stress and insulin resistance. Free Radic Biol Med 2007;42:1089-97.

87. Parik T, Allikmets K, Teesalu R, Zilmer M. Evidence for oxidative stress in essential hypertension: Perspective for antioxidant therapy. J Cardiovasc Risk 1996;3:49-54.

88. Uysal M, Bulur H, Sener D, Oz H. Lipid peroxidation in patients with essential hypertension. Int J Clin Pharmacol Ther Toxicol 1986;24:474-6.

89. Kashyap MK, Yadav V, Sherawat BS, et al. Different antioxidants status, total antioxidant power and free radicals in essential hypertension. Mol Cell Biochem 2005;277:89-99.

90. Aruoma OI, Halliwell B, Hoey BM, Butler J. The antioxidant action of $\mathrm{N}$-acetylcysteine: Its reaction with hydrogen peroxide, hydroxyl radical, superoxide, and hypochlorous acid. Free Radic Biol Med 1989;6:593-7.

91. Kharazmi A, Nielsen H, Schiotz PO. N-acetylcysteine inhibits human neutrophil and monocyte chemotaxis and oxidative metabolism. Int J Immunopharmacol 1988;10:39-46.

92. Sagrista ML, Garcia AE, Africa De Madariaga M, Mora M. Antioxidant and pro-oxidant effect of the thiolic compounds $\mathrm{N}$-acetyl-L-cysteine and glutathione against free radical-induced lipid peroxidation. Free Radic Res 2002;36:329-40.

93. Zachwieja J, Zaniew M, Bobkowski W, et al. Beneficial in vitro effect of $\mathrm{N}$-acetyl-cysteine on oxidative stress and apoptosis. Pediatr Nephrol 2005;20:725-31.

94. Ferrari R, Ceconi C, Curello S, et al. Oxygen free radicals and myocardial damage: Protective role of thiol-containing agents. Am J Med 1991;91:95S-105S.

95. Xia Z, Guo Z, Nagareddy PR, Yuen V, Yeung E, McNeill JH. Antioxidant $\mathrm{N}$-acetylcysteine restores myocardial Mn-SOD activity and attenuates myocardial dysfunction in diabetic rats. Eur J Pharmacol 2006;544:118-25.

96. Bourraindeloup M, Adamy C, Candiani G, et al. N-acetylcysteine treatment normalizes serum tumor necrosis factor-alpha level and hinders the progression of cardiac injury in hypertensive rats. Circulation 2004;110:2003-9.

97. Jensen T, Kharazmi A, Schiotz PO, et al. Effect of oral $\mathrm{N}$-acetylcysteine administration on human blood neutrophil and monocyte function. APMIS 1988;96:62-7.

98. De Mattia G, Bravi MC, Laurenti O, et al. Reduction of oxidative stress by oral $\mathrm{N}$-acetyl-L-cysteine treatment decreases plasma soluble vascular cell adhesion molecule-1 concentrations in non-obese, non-dyslipidaemic, normotensive, patients with non-insulin-dependent diabetes. Diabetologia 1998;41:1392-6.

99. Scherrer U, Randin D, Vollenweider P, Vollenweider L, Nicod P. Nitric oxide release accounts for insulin's vascular effects in humans. J Clin Invest 1994;94:2511-5.

100. Kahn NN, Acharya K, Bhattacharya S, et al. Nitric oxide: The 'second messenger' of insulin. IUBMB Life 2000;49:441-50.

101. Montagnani M, Ravichandran LV, Chen H, Esposito DL, Quon MJ. Insulin receptor substrate- 1 and phosphoinositide-dependent kinase-1 are required for insulin-stimulated production of nitric oxide in endothelial cells. Mol Endocrinol 2002;16:1931-42.

102. Zeng G, Nystrom FH, Ravichandran LV, et al. Roles for insulin receptor, PI3-kinase, and akt in insulin-signaling pathways related to production of nitric oxide in human vascular endothelial cells. Circulation 2000;101:1539-45.

103. Kamide K, Hori MT, Zhu JH, Barrett JD, Eggena P, Tuck ML. Insulin-mediated growth in aortic smooth muscle and the vascular renin-angiotensin system. Hypertension 1998;32:482-7.

104. Kamide K, Rakugi H, Nagai M, et al. Insulin-mediated regulation of the endothelial renin-angiotensin system and vascular cell growth. J Hypertens 2004;22:121-7.

105. Tiwari S, Riazi S, Ecelbarger CA. Insulin's impact on renal sodium transport and blood pressure in health, obesity, and diabetes. Am J Physiol Renal Physiol 2007;293:F974-84.

106. DeFronzo RA, Ferrannini E. Insulin resistance. A multifaceted syndrome responsible for NIDDM, obesity, hypertension, dyslipidemia, and atherosclerotic cardiovascular disease. Diabetes Care 1991;14:173-94.

107. Zavaroni I, Mazza S, Dall'Aglio E, Gasparini P, Passeri M, Reaven GM. Prevalence of hyperinsulinaemia in patients with high blood pressure. J Intern Med 1992;231:235-40.

108. Hedblad B, Nilsson P, Engstrom G, Berglund G, Janzon L. Insulin resistance in non-diabetic subjects is associated with increased incidence of myocardial infarction and death. Diabet Med 2002;19:470-5.

109. Harano Y, Suzuki M, Koyama Y, et al. Multifactorial insulin resistance and clinical impact in hypertension and cardiovascular diseases. J Diabetes Complications 2002;16:19-23.

110. Beatty OL, Harper R, Sheridan B, Atkinson AB, Bell PM. Insulin resistance in offspring of hypertensive parents. BMJ 1993;307:92-6.

111. Hulman S, Falkner B, Freyvogel N. Insulin resistance in the conscious spontaneously hypertensive rat: Euglycemic hyperinsulinemic clamp study. Metabolism 1993;42:14-8.

112. Mondon CE, Reaven GM, Azhar S, Lee CM, Rabkin R. Abnormal insulin metabolism by specific organs from rats with spontaneous hypertension. Am J Physiol 1989;257:E491-8.

113. Lembo G, Iaccarino G, Vecchione C, Rendina V, Trimarco B. Insulin modulation of vascular reactivity is already impaired in prehypertensive spontaneously hypertensive rats. Hypertension 1995;26:290-3.

114. Giner V, Coca A, de la Sierra A. Increased insulin resistance in salt sensitive essential hypertension. J Hum Hypertens 2001;15:481-5.

115. Fuenmayor N, Moreira E, Cubeddu LX. Salt sensitivity is associated with insulin resistance in essential hypertension. Am J Hypertens 1998;11:397-402.

116. Sharma AM, Schorr U, Distler A. Insulin resistance in young salt-sensitive normotensive subjects. Hypertension 1993;21:273-9.

117. Ogihara T, Asano T, Ando K, et al. Insulin resistance with enhanced insulin signaling in high-salt diet-fed rats. Diabetes 2001;50:573-83.

118. Ogihara T, Asano T, Ando K, et al. High-salt diet enhances insulin signaling and induces insulin resistance in dahl salt-sensitive rats. Hypertension 2002;40:83-9.

119. Zecchin HG, Bezerra RM, Carvalheira JB, et al. Insulin signalling pathways in aorta and muscle from two animal models of insulin resistance - the obese middle-aged and the spontaneously hypertensive rats. Diabetologia 2003;46:479-91.

120. Kahn CR, Saad MJ. Alterations in insulin receptor and substrate phosphorylation in hypertensive rats. J Am Soc Nephrol 1992;3:S69-77.

121. Ammon HP, Muller PH, Eggstein M, et al. Increase in glucose consumption by acetylcysteine during hyperglycemic clamp. A study with healthy volunteers. Arzneimittelforschung 1992;42:642-5. 
122. Hildebrandt W, Hamann A, Krakowski-Roosen H, et al. Effect of thiol antioxidant on body fat and insulin reactivity. J Mol Med 2004;82:336-44

123. Fulghesu AM, Ciampelli M, Muzj G, et al. N-acetyl-cysteine treatment improves insulin sensitivity in women with polycystic ovary syndrome. Fertil Steril 2002;77:1128-35.

124. Padgett CM, Whorton AR. Glutathione redox cycle regulates nitric oxide-mediated glyceraldehyde-3-phosphate dehydrogenase inhibition. Am J Physiol 1997;272:C99-108.

125. Zeng J, Davies MJ. Evidence for the formation of adducts and S-(carboxymethyl)cysteine on reaction of alpha-dicarbonyl compounds with thiol groups on amino acids, peptides, and proteins. Chem Res Toxicol 2005;18:1232-41.

126. Thornalley PJ, Battah S, Ahmed N, et al. Quantitative screening of advanced glycation endproducts in cellular and extracellular proteins by tandem mass spectrometry. Biochem J 2003;375:581-92.

127. Thorpe SR, Baynes JW. Maillard reaction products in tissue proteins: New products and new perspectives. Amino Acids 2003;25:275-81.

128. Dutta U, Cohenford MA, Dain JA. Nonenzymatic glycation of DNA nucleosides with reducing sugars. Anal Biochem 2005;345:171-80.

129. Park YS, Koh YH, Takahashi M, et al. Identification of the binding site of methylglyoxal on glutathione peroxidase: Methylglyoxal inhibits glutathione peroxidase activity via binding to glutathione binding sites arg 184 and 185. Free Radic Res 2003;37:205-11.

130. Riboulet-Chavey A, Pierron A, Durand I, Murdaca J, Giudicelli J, Van Obberghen E. Methylglyoxal impairs the insulin signaling pathways independently of the formation of intracellular reactive oxygen species. Diabetes 2006;55:1289-99.

131. Jia X, Wu L. Accumulation of endogenous methylglyoxal impaired insulin signaling in adipose tissue of fructose-fed rats. Mol Cell Biochem 2007;306:133-9.

132. Jia X, Olson DJ, Ross AR, Wu L. Structural and functional changes in human insulin induced by methylglyoxal. FASEB J 2006;20:1555-7.

133. Xu B, Chibber R, Ruggiero D, Kohner E, Ritter J, Ferro A. Impairment of vascular endothelial nitric oxide synthase activity by advanced glycation end products. FASEB J 2003;17:1289-91.

134. Lee HJ, Howell SK, Sanford RJ, Beisswenger PJ. Methylglyoxal can modify GAPDH activity and structure. Ann NY Acad Sci 2005; 1043:135-45.

135. Collison KS, Parhar RS, Saleh SS, et al. RAGE-mediated neutrophil dysfunction is evoked by advanced glycation end products (AGEs). J Leukoc Biol 2002;71:433-44.

136. Horiuchi S, Sakamoto Y, Sakai M. Scavenger receptors for oxidized and glycated proteins. Amino Acids 2003;25:283-92.

137. Dargel R. Lipid peroxidation - a common pathogenetic mechanism? Exp Toxicol Pathol 1992;44:169-81.

138. O’Brien PJ, Siraki AG, Shangari N. Aldehyde sources, metabolism, molecular toxicity mechanisms, and possible effects on human health. Crit Rev Toxicol 2005;35:609-62.

139. Thornalley PJ. The glyoxalase system in health and disease. Mol Aspects Med 1993;14:287-371.

140. Lu C, He JC, Cai W, Liu H, Zhu L, Vlassara H. Advanced glycation endproduct (AGE) receptor 1 is a negative regulator of the inflammatory response to AGE in mesangial cells. Proc Natl Acad Sci USA 2004;101:11767-72.

141. Vasdev S, Gill V, Parai S, Gadag V. Dietary lipoic acid supplementation attenuates hypertension in Dahl salt sensitive rats. Mol Cell Biochem 2005;275:135-41.

142. Midaoui AE, Elimadi A, Wu L, Haddad PS, de Champlain J. Lipoic acid prevents hypertension, hyperglycemia, and the increase in heart mitochondrial superoxide production. Am J Hypertens 2003;16:173-9.

143. Wang X, Jia X, Chang T, Desai K, Wu L. Attenuation of hypertension development by scavenging methylglyoxal in fructose-treated rats. J Hypertens 2008;26:765-72.

144. Wang X, Chang T, Jiang B, Desai K, Wu L. Attenuation of hypertension development by aminoguanidine in spontaneously hypertensive rats: Role of methylglyoxal. Am J Hypertens 2007;20:629-36

145. Wang X, Desai K, Chang T, Wu L. Vascular methylglyoxal metabolism and the development of hypertension. J Hypertens 2005;23:1565-1573.
146. Wang X, Desai K, Clausen JT, Wu L. Increased methylglyoxal and advanced glycation end products in kidney from spontaneously hypertensive rats. Kidney Int 2004;66:2315-21.

147. Wu L, Juurlink BH. Increased methylglyoxal and oxidative stress in hypertensive rat vascular smooth muscle cells. Hypertension 2002;39:809-14.

148. Wu L. The pro-oxidant role of methylglyoxal in mesenteric artery smooth muscle cells. Can J Physiol Pharmacol 2005;83:63-8.

149. Wautier MP, Chappey O, Corda S, Stern DM, Schmidt AM, Wautier JL. Activation of NADPH oxidase by AGE links oxidant stress to altered gene expression via RAGE. Am J Physiol Endocrinol Metab 2001;280:E685-94

150. Cohen MP, Shea E, Chen S, Shearman CW. Glycated albumin increases oxidative stress, activates NF-kappa B and extracellular signal-regulated kinase (ERK), and stimulates ERK-dependent transforming growth factor-beta 1 production in macrophage RAW cells. J Lab Clin Med 2003;141:242-9.

151. Bierhaus A, Chevion S, Chevion M, et al. Advanced glycation end product-induced activation of NF-kappaB is suppressed by alpha-lipoic acid in cultured endothelial cells. Diabetes 1997;46:1481-90

152. Iehara N, Takeoka H, Yamada Y, Kita T, Doi T. Advanced glycation end products modulate transcriptional regulation in mesangial cells. Kidney Int 1996;50:1166-72.

153. Fukami K, Ueda S, Yamagishi S, et al. AGEs activate mesangial TGF-beta-Smad signaling via an angiotensin II type I receptor interaction. Kidney Int 2004;66:2137-47.

154. Chang T, Wang R, Wu L. Methylglyoxal-induced nitric oxide and peroxynitrite production in vascular smooth muscle cells. Free Radic Biol Med 2005;38:286-93.

155. Wu S, Song T, Zhou S, et al. Involvement of $\mathrm{Na}^{+} / \mathrm{H}^{+}$exchanger 1 in advanced glycation end products-induced proliferation of vascular smooth muscle cell. Biochem Biophys Res Commun 2008;375:384-9.

156. He R, Qu AJ, Mao JM, Wang X, Sun W. Synergistic proliferation induced by insulin and glycated serum albumin in rat vascular smooth muscle cells. Sheng Li Xue Bao 2007;59:1-7.

157. Vasdev S, Ford CA, Longerich L, Parai S, Gadag V. Aldehyde induced hypertension in rats: Prevention by $\mathrm{N}$-acetylcysteine. Artery 1998;23:10-36.

158. McNulty M, Mahmud A, Feely J. Advanced glycation end-products and arterial stiffness in hypertension. Am J Hypertens 2007;20:242-7.

159. Sugiyama S, Miyata T, Ueda Y, et al. Plasma levels of pentosidine in diabetic patients: An advanced glycation end product. J Am Soc Nephrol 1998;9:1681-8.

160. Leoncini G, Maresca M, Bonsignore A. The effect of methylglyoxal on the glycolytic enzymes. FEBS Lett 1980;117:17-8.

161. Unoki H, Bujo H, Yamagishi S, Takeuchi M, Imaizumi T, Saito Y. Advanced glycation end products attenuate cellular insulin sensitivity by increasing the generation of intracellular reactive oxygen species in adipocytes. Diabetes Res Clin Pract 2007;76:236-44.

162. Haber CA, Lam TK, Yu Z, et al. N-acetylcysteine and taurine prevent hyperglycemia-induced insulin resistance in vivo: Possible role of oxidative stress. Am J Physiol Endocrinol Metab 2003;285:E744-53.

163. Taddei S, Ghiadoni L, Virdis A, Versari D, Salvetti A. Mechanisms of endothelial dysfunction: Clinical significance and preventive non-pharmacological therapeutic strategies. Curr Pharm Des 2003;9:2385-402.

164. Taddei S, Virdis A, Ghiadoni L, Magagna A, Salvetti A. Vitamin C improves endothelium-dependent vasodilation by restoring nitric oxide activity in essential hypertension. Circulation 1998;97:2222-9.

165. Ibarra M, Meneses A, Ransanz V, Castillo C, Hong E. Changes in endothelium-dependent vascular responses associated with spontaneous hypertension and age in rats. Arch Med Res 1995;26 Spec No:S177-83.

166. Kamata K, Yamashita K. Insulin resistance and impaired endothelium-dependent renal vasodilatation in fructose-fed hypertensive rats. Res Commun Mol Pathol Pharmacol 1999;103:195-210.

167. Manning RD Jr, Hu L, Tan DY, Meng S. Role of abnormal nitric oxide systems in salt-sensitive hypertension. Am J Hypertens 2001;14:68S-73S. 
168. Scherrer U, Sartori C. Defective nitric oxide synthesis: A link between metabolic insulin resistance, sympathetic overactivity and cardiovascular morbidity. Eur J Endocrinol 2000;142:315-23.

169. Beckman JS, Beckman TW, Chen J, Marshall PA, Freeman BA. Apparent hydroxyl radical production by peroxynitrite: Implications for endothelial injury from nitric oxide and superoxide. Proc Natl Acad Sci USA 1990;87:1620-4.

170. Xia Y, Tsai AL, Berka V, Zweier JL. Superoxide generation from endothelial nitric-oxide synthase. $\mathrm{A} \mathrm{Ca}^{2+} /$ calmodulin-dependent and tetrahydrobiopterin regulatory process. J Biol Chem 1998;273:25804-8.

171. Ramasamy S, Drummond GR, Ahn J, et al. Modulation of expression of endothelial nitric oxide synthase by nordihydroguaiaretic acid, a phenolic antioxidant in cultured endothelial cells. Mol Pharmacol 1999;56:116-23.

172. Xia Z, Liu M, Wu Y, et al. N-acetylcysteine attenuates TNF-alphainduced human vascular endothelial cell apoptosis and restores eNOS expression. Eur J Pharmacol 2006;550:134-42.

173. Xia Z, Nagareddy PR, Guo Z, Zhang W, McNeill JH. Antioxidant $\mathrm{N}$-acetylcysteine restores systemic nitric oxide availability and corrects depressions in arterial blood pressure and heart rate in diabetic rats. Free Radic Res 2006;40:175-84.

174. Pieper GM, Siebeneich W. Oral administration of the antioxidant, $\mathrm{N}$-acetylcysteine, abrogates diabetes-induced endothelial dysfunction. J Cardiovasc Pharmacol 1998;32:101-5.

175. Andrews NP, Prasad A, Quyyumi AA. N-acetylcysteine improves coronary and peripheral vascular function. J Am Coll Cardiol 2001;37:117-23.

176. Zembowicz A, Hatchett RJ, Radziszewski W, Gryglewski RJ. Inhibition of endothelial nitric oxide synthase by ebselen. Prevention by thiols suggests the inactivation by ebselen of a critical thiol essential for the catalytic activity of nitric oxide synthase. J Pharmacol Exp Ther 1993;267:1112-8.

177. Gandley RE, Tyurin VA, Huang W, et al. S-nitrosoalbuminmediated relaxation is enhanced by ascorbate and copper: Effects in pregnancy and preeclampsia plasma. Hypertension 2005;45:21-7.

178. Dicks AP, Williams DL. Generation of nitric oxide from $\mathrm{S}$-nitrosothiols using protein-bound $\mathrm{Cu}^{2+}$ sources. Chem Biol 1996:3:655-9.

179. Nikitovic D, Holmgren A. S-nitrosoglutathione is cleaved by the thioredoxin system with liberation of glutathione and redox regulating nitric oxide. J Biol Chem 1996;271:19180-5.

180. Jensen DE, Belka GK, Du Bois GC. S-nitrosoglutathione is a substrate for rat alcohol dehydrogenase class III isoenzyme. Biochem J 1998;331:659-68.

181. Hoque A, Bates JN, Lewis SJ. In vivo evidence that L-Snitrosocysteine may exert its vasodilator effects by interaction with thiol residues in the vasculature. Eur J Pharmacol 1999;384:169-72.

182. Kowaluk EA, Fung HL. Spontaneous liberation of nitric oxide cannot account for in vitro vascular relaxation by S-nitrosothiols. J Pharmacol Exp Ther 1990;255:1256-64.

183. Ricardo KF, Shishido SM, de Oliveira MG, Krieger MH. Characterization of the hypotensive effect of S-nitroso-Nacetylcysteine in normotensive and hypertensive conscious rats. Nitric Oxide 2002;7:57-66.

184. Keaney JF Jr, Simon DI, Stamler JS, et al. NO forms an adduct with serum albumin that has endothelium-derived relaxing factor-like properties. J Clin Invest 1993;91:1582-9.

185. Lewis SJ, Owen JR, Bates JN. S-nitrosocysteine elicits hemodynamic responses similar to those of the Bezold-Jarisch reflex via activation of stereoselective recognition sites. Eur J Pharmacol 2006;531:254-8.

186. Davisson RL, Travis MD, Bates JN, Lewis SJ. Hemodynamic effects of L- and D-S-nitrosocysteine in the rat. Stereoselective S-nitrosothiol recognition sites. Circ Res 1996;79:256-62.

187. Zhang Y, Hogg N. The mechanism of transmembrane S-nitrosothiol transport. Proc Natl Acad Sci USA 2004;101:7891-6.

188. Afanas'ev IB. Signaling functions of free radicals superoxide and nitric oxide under physiological and pathological conditions. Mol Biotechnol 2007;37:2-4.

189. Xu L, Eu JP, Meissner G, Stamler JS. Activation of the cardiac calcium release channel (ryanodine receptor) by poly-S. nitrosylation. Science 1998;279:234-7.

190. Marshall HE, Stamler JS. Inhibition of NF-kappa B by S-nitrosylation. Biochemistry 2001;40:1688-93.
191. Zaman K, Palmer LA, Doctor A, Hunt JF, Gaston B. Concentration-dependent effects of endogenous S-nitrosoglutathione on gene regulation by specificity proteins Sp3 and Sp1. Biochem J 2004;380:67-74.

192. Padgett CM, Whorton AR. S-nitrosoglutathione reversibly inhibits GAPDH by S-nitrosylation. Am J Physiol 1995;269:C739-49.

193. Ogihara T, Asano T, Ando K, et al. Angiotensin II-induced insulin resistance is associated with enhanced insulin signaling. Hypertension 2002;40:872-9.

194. Thomas MC, Tikellis C, Burns WM, et al. Interactions between renin angiotensin system and advanced glycation in the kidney. J Am Soc Nephrol 2005;16:2976-84.

195. Tuck ML, Bounoua F, Eslami P, Nyby MD, Eggena P, Corry DB. Insulin stimulates endogenous angiotensin II production via a mitogen-activated protein kinase pathway in vascular smooth muscle cells. J Hypertens 2004;22:1779-85.

196. Luvara G, Pueyo ME, Philippe M, et al. Chronic blockade of NO synthase activity induces a proinflammatory phenotype in the arterial wall: Prevention by angiotensin w antagonism. Arterioscler Thromb Vasc Biol 1998;18:1408-16.

197. Folli F, Kahn CR, Hansen H, Bouchie JL, Feener EP. Angiotensin II inhibits insulin signaling in aortic smooth muscle cells at multiple levels. A potential role for serine phosphorylation in insulin/ angiotensin II crosstalk. J Clin Invest 1997;100:2158-69.

198. Wei Y, Sowers JR, Nistala R, et al. Angiotensin II-induced NADPH oxidase activation impairs insulin signaling in skeletal muscle cells. J Biol Chem 2006;281:35137-46.

199. Landmesser U, Cai H, Dikalov S, et al. Role of p47(phox) in vascular oxidative stress and hypertension caused by angiotensin II. Hypertension 2002;40:511-5.

200. Wolf G, Jablonski K, Schroeder R, Reinking R, Shankland SJ, Stahl RA. Angiotensin II-induced hypertrophy of proximal tubular cells requires p27Kip1. Kidney Int 2003;64:71-81.

201. Griendling KK, Minieri CA, Ollerenshaw JD, Alexander RW. Angiotensin II stimulates NADH and NADPH oxidase activity in cultured vascular smooth muscle cells. Circ Res 1994;74:1141-8.

202. Boesgaard S, Aldershvile J, Poulsen HE, Christensen S, Dige-Petersen $\mathrm{H}$, Giese J. N-acetylcysteine inhibits angiotensin converting enzyme in vivo. J Pharmacol Exp Ther 1993;265:1239-44.

203. Touyz RM, Tabet F, Schiffrin EL. Redox-dependent signalling by angiotensin II and vascular remodelling in hypertension. Clin Exp Pharmacol Physiol 2003;30:860-6.

204. Ullian ME, Gelasco AK, Fitzgibbon WR, Beck CN, Morinelli TA. $\mathrm{N}$-acetylcysteine decreases angiotensin II receptor binding in vascular smooth muscle cells. J Am Soc Nephrol 2005; 16:2346-53.

205. Szabo C. Hydrogen sulphide and its therapeutic potential. Nat Rev Drug Discov 2007;6:917-35.

206. Webb GD, Lim LH, Oh VM, et al. Contractile and vasorelaxant effects of hydrogen sulfide and its biosynthesis in the human internal mammary artery. J Pharmacol Exp Ther 2008;324:876-82

207. Ali MY, Ping CY, Mok YY, et al. Regulation of vascular nitric oxide in vitro and in vivo; a new role for endogenous hydrogen sulphide? Br J Pharmacol 2006;149:625-34

208. Zhong G, Chen F, Cheng Y, Tang C, Du J. The role of hydrogen sulfide generation in the pathogenesis of hypertension in rats induced by inhibition of nitric oxide synthase. J Hypertens 2003;21:1879-85.

209. Yan H, Du J, Tang C. The possible role of hydrogen sulfide on the pathogenesis of spontaneous hypertension in rats. Biochem Biophys Res Commun 2004;313:22-7.

210. Chen L, Ingrid S, Ding Y, et al. Imbalance of endogenous homocysteine and hydrogen sulfide metabolic pathway in essential hypertensive children. Chin Med J 2007;120:389-93.

211. Valderrabano F, Gomez-Campdera F, Jones EH. Hypertension as cause of end-stage renal disease: Lessons from international registries. Kidney Int Suppl 1998;68:S60-6.

212. United States Renal Data Systems Annual Report 2006. Atlas of chronic kidney disease and end-stage renal disease in the united states. Am J Kidney Dis 2007;49:S67-84.

213. Martinez-Maldonado M. Hypertension in end-stage renal disease. Kidney Int Suppl 1998;68:S67-72. 
214. Sarafidis PA, Ruilope LM. Insulin resistance, hyperinsulinemia, and renal injury: Mechanisms and implications. Am J Nephrol 2006;26:232-44.

215. Bataineh A, Raij L. Angiotensin II, nitric oxide, and end-organ damage in hypertension. Kidney Int Suppl 1998;68:S14-9.

216. Grandi AM, Maresca AM. Blockade of the renin-angiotensinaldosterone system: Effects on hypertensive target organ damage. Cardiovasc Hematol Agents Med Chem 2006;4:219-28.

217. Baumann M, Stehouwer C, Scheijen J, et al. N epsilon(carboxymethyl)lysine during the early development of hypertension. Ann NY Acad Sci 2008;1126:201-4.
218. Johnson RJ, Gordon KL, Giachelli C, Kurth T, Skelton MM, Cowley AW Jr. Tubulointerstitial injury and loss of nitric oxide synthases parallel the development of hypertension in the Dahl-SS rat. J Hypertens 2000;18:1497-505.

219. Shimizu MH, Coimbra TM, de Araujo M, Menezes LF, Seguro AC. $\mathrm{N}$-acetylcysteine attenuates the progression of chronic renal failure. Kidney Int 2005;68:2208-17.

220. Heyman SN, Goldfarb M, Shina A, Karmeli F, Rosen S. $\mathrm{N}$-acetylcysteine ameliorates renal microcirculation: Studies in rats. Kidney Int 2003;63:634-41. 